\title{
PERIODIZACE EPIŠŇŮROVÉHO P̌̌IKARPTASKÉHO KULTURNÍHO KOMPLEXU NA MORAVĚ A VE SLEZSKU
}

\author{
J A ROSLAV PE ŠKA - MIROSLAV KR ÁLÍK \\ Studii autoři věnuji prof. Jozefovi Bátorovi k jeho 70. narozeninám.
}

\begin{abstract}
Internal Periodization of the Epicorded Carpathian Cultural Complex in Moravia and Silesia. The article summarises the previous research on the Epi-corded Carpathian Cultural Complex (ECCC) in Moravia and Silesia, particularly with respect to the currently used terminology and internal periodisation. Apart from typo-chronology also some methods of multidimensional statistics of several hundred grave complexes were used, whose results are mutually compared and correlated with a small series of absolute dates. Despite some inaccuracies or discrepancies, the earlier published postulates about the internal development of material culture of the ECCC were proved correct. The only representative of this development in East Moravia and in the southern part of Upper Silesia is the Nitra/Mierzanowice Culture (the formerly used Chłopice-Veselé Group/Culture represents 2 chronologically different stages). The culture is newly divided into 5 phases: Proto-Nitra Culture, Early Nitra Culture, Old, Classical and Post-classical Nitra Culture with clear characteristics of all phases, selected examples of typical representatives and distinction of 6 burial horizons in the cemetery of Holešov. Due to similarity of material, the Epi-corded finds north of the Moravian Gate and in Silesia are suggested to be classified as Mierzanowice Culture, and the finds south of the Moravian Gate and in SW Slovakia should be classified as Nitra Culture.
\end{abstract}

Keywords: Early Bronze Age, Epi-corded Carpathian Cultural Complex, Nitra Culture, Mierzanowice Culture, typochronology, multidimensional statistics, terminology, internal periodization.

\section{ÚVOD A DĚJINY VÝZKUMU}

Přestože první nálezy zařaditelné do epišňůrového přikarpatského kulturního komplexu (EPKK) jsou z východní Moravy známy již z konce 19. a z počátku a první poloviny 20. stol. (hrob ze Strážnice-Za drahama - Dvorský 1914, 485-487, obr. 116; Palliardi 1893, 138; Př́́kaz - Ondráček 1963, 405, 406, obr. 130; Wankel 1889; Drahlova - Kovářová 1928; Ondráček 1963, 406; Sudoměřic - Maška 1907; pohřebiště Uherské Hradiště-Sady - Horsák 1941; pohřebiště Ostrožská Nová Ves - Hrubý 1948; Tihelka 1953, 302, obr. 28; Hrubý a j. 1956; Menoušková/Fikrle 2019), s výjimkou výzkumu pohřebiště v Holešově v letech 1950, 1964-1970 (Ondráček 1963, 407-409; 1972; Ondráček/Šebela 1985; Struhala 1951) neprobíhal archeologický výzkum o této entitě starší doby bronzové nijak systematicky, a proto lze konstatovat platnou tezi, že naše poznatky o EPKK jsou ve srovnání s Malopolskem nebo jihozápadním Slovenskem stále velice mezerovité. Změna nastává s realizací velkoplošných záchranných výzkumů poslední doby a odkryvem jak menších (Kroměříž, Hulín 1, Slatinice), tak velkých (Hulín 3, Hroznová Lhota) kostrových pohřebišt', ale především rovinných sídlišt' (Berkovec/Peška 2005b; Kadrow/Peška 1999; Kadrow/Peška/Vitula 2000; Peška 2012; Šmíd 2012).

Na moravskoslezském pomezí (Opavsko) se díky záchranné archeologii v poslední době počet epišňůrových lokalit postupně navyšuje (Opava-Kylešovice, Opava-Kateřinky, Opava-Vávrovice, Holasovice-Loděnice), většina materiálu je však dosud nezpracovaná a nepublikovaná (cf. Šebela 2014). Naše nekropole jak po stránce prostorové, tak i chronologické plynule navazují na epišňưrová (mierzanovická) pohřebiště na polské straně Horního Slezska (Kornice, Dzielnica, Racibórz).

\section{PRAMENNÁ BÁZE, ROZSAH A STRUKTURA OSÍDLENÍ}

Převahu pramenné základny EPKK tvoří tradičně velká (Holešov, Hulín 3, Hroznová Lhota) nebo menší (Miškovice, Hulín 1, Kroměříž-U sv. Františka, Uherské Hradiště-Sady, Sudoměřice I, Slatinice, Polešovice, Opava-Vávrovice, Opava-Kateřinky, Opava-Kylešovice) skupinová kostrová pohřebiště. K dispozici jsou i jednotlivé hroby (Dolní Němčí, Sudoměřice II). Velice důležitou skutečností se stal objev epišňůrových sídlišt s desítkami běžných zahloubených jam, hliníků a dalších objektů, jen velmi málo odlišná od jiných pravěkých oikumen (Přáslavice, Přerov-Předmostí-Dluhonice, Hulín 1, 2 , 4, Holešov-Na větřáku). Společným jmenovatelem je jim dosavadní absence půdorysů nadzemních staveb, $\mathrm{u}$ nichž předpokládáme srubové konstrukce (Osek nad Bečvou 1 - Peška/Tajer 2014; 2015a). K nim přistupuje řada ojedinělých, resp. 


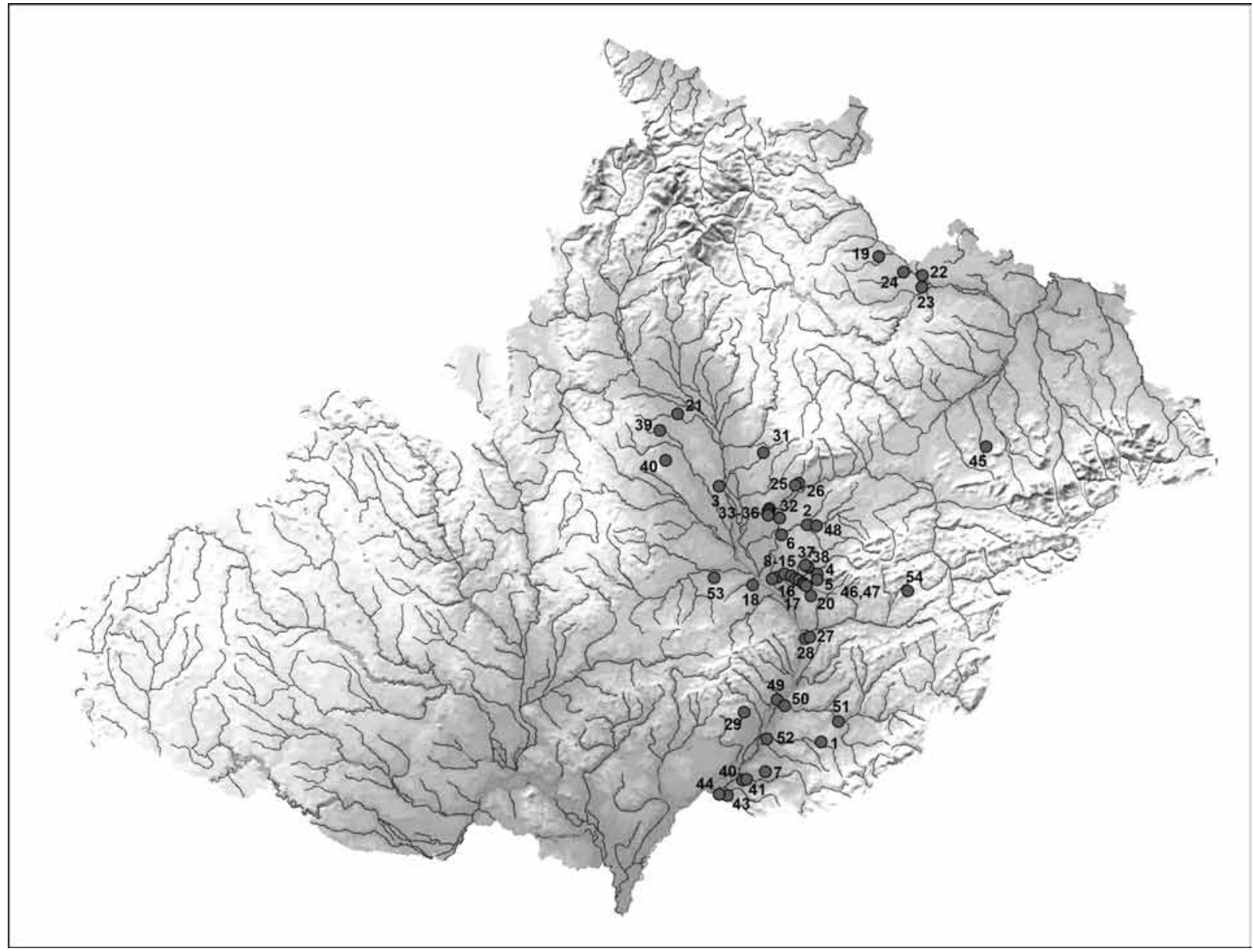

Obr. 1. Mapa osídlení nitranskou kulturou na území Moravy a Slezska. 1 - Dolní Němčí-dům (p. č. 506); 2 - Domaželice-bez lokace; 3 - Drahlov-zahrada p. Babiánka; 4 - Holešov I-Zdražilovsko; 5 - Holešov II-Větrák, Na větřáku; 6 - Horní Moštěnice-Příčky; 7 - Hroznová Lhota-Přední čtvrtky od Žabince; 8 - Hulín I-Stančíkova skála, Za potůčkem; 9 - Hulín II-Přídanky; 10 - Hulín III-Višňovce; 11 - Hulín IV-Nivky; 12 - Hulín V (Hulín 1)-U Isidorka; 13 - Hulín VI (Hulín 2)-U Isidorka; 14 - Hulín VII (Hulín 3)-U potůčku; 15 - Hulín VIII (Hulín 4)-Vrbičné; 16 - Hulín-Pravčice 1-U obrázku; 17 - Količín 1-Kopaniny (Šeblínek?); 18 - Kroměříž-Újezd u sv. Františka; 19 - Loděnice (Holasovice-Loděnice); 20 Míškovice-Křemenná; 21 - Náklo-Př́íkazy-Hráč, Vaňkova cihelna, cihelna; 22 - Opava-Kateřinky-Na Hoštických lukách; 23 - Opava-Kylešovice-Na stanech; 24 - Opava-Vávrovice-Krásné pole; 25 - Osek nad Bečvou 1-Horní Újezdy; 26 - Osek nad Bečvou 2-Nademlýní; 27 - Otrokovice-Kvítkovice-Chmelín; 28 -Otrokovice-Kvítkovice-Nábřeží; 29-Polešovice-Nivy; 30 - Pravčice 1-Nivky; 31 - Přáslavice-Díly pod dědinou; 32 - Přerov; 33 - Přerov-Předmost 7-Malé Předmostí; 34 - Přerov-Předmostí-hliník Hanáckých cihelen; 35 - Přerov-Předmostí 8-Hejnice; 36 - Přerov-Předmostí/Dluhonice-Díly a Dolní Újezd; 37 - Rymice I; 38 - Rymice II-Blaní, Dolní Blaní (p. č. 290); 39 - Senice na Hané-obec; 40 - Slatinice-Trávníky; 41 Strážnice; 42 - Strážnice-Za drahama; 43 - Sudoměřice I; 44 - Sudoměřice II-pískovna; 45 - Štramberk-Kotouč-Čertova díra; 46 - Třebětice I-Padělky (č. p. 363); 47 - Třebětice II-Koleno; 48 - Turovice-Díly za vodou; 49 - Uherské Hradiště-řeka Morava pod sokolským domem; 50 - Uherské Hradiště-Sady (Derfle)-Kotvice (p. č. 500/1); 51 - Uherský Brod-Kyčkov; 52 - Uherský Ostroh; 53 - Vitčice; 54 - Všemina.

povrchových nálezů keramiky s typickou šňůrovou výzdobou, broušené industrie, příp. dalších předmětů, signalizující existenci hrobů/pohřebišt (celé nádoby, sekeromlaty) nebo sídlište (větší hrncovité nádoby etc.). Největší pohřebiště v Holešově bylo zveřejněno svého času formou katalogu (Ondráček/Šebela 1985) a dílčí studií zabývající se pravidelností pohřebního ritu za pomoci faktorové analýzy (Šmejda 2003). Další velká nekropole (Hulín 3) se stala předmětem diplomové práce
(Schimerová 2014) a zatím druhé největší pohřebiště z Hroznové Lhoty (115 hrobů) bylo dosud přiblíženo jen dílčí studií kamenných projektilů (Kaňákovál Šmerda/Nosek 2016). S výjimkou dílčích příspěvků se zveřejněním materiálu z jednotlivých nalezišt nebo mikroregionů (Berkovec/Peška 2005b; Kadrow/ Peška 1999; Kadrow/Peška/Vitula 2000; Menouškovál Fikrle 2019; Peška 2012; 2013; 2016; Peška a d. 2005; Peška/Šebela 1992; Peška/Tajer 2014; 2015a; 2015b; Šebela a d. 1990), včetně shrnutí problematiky 


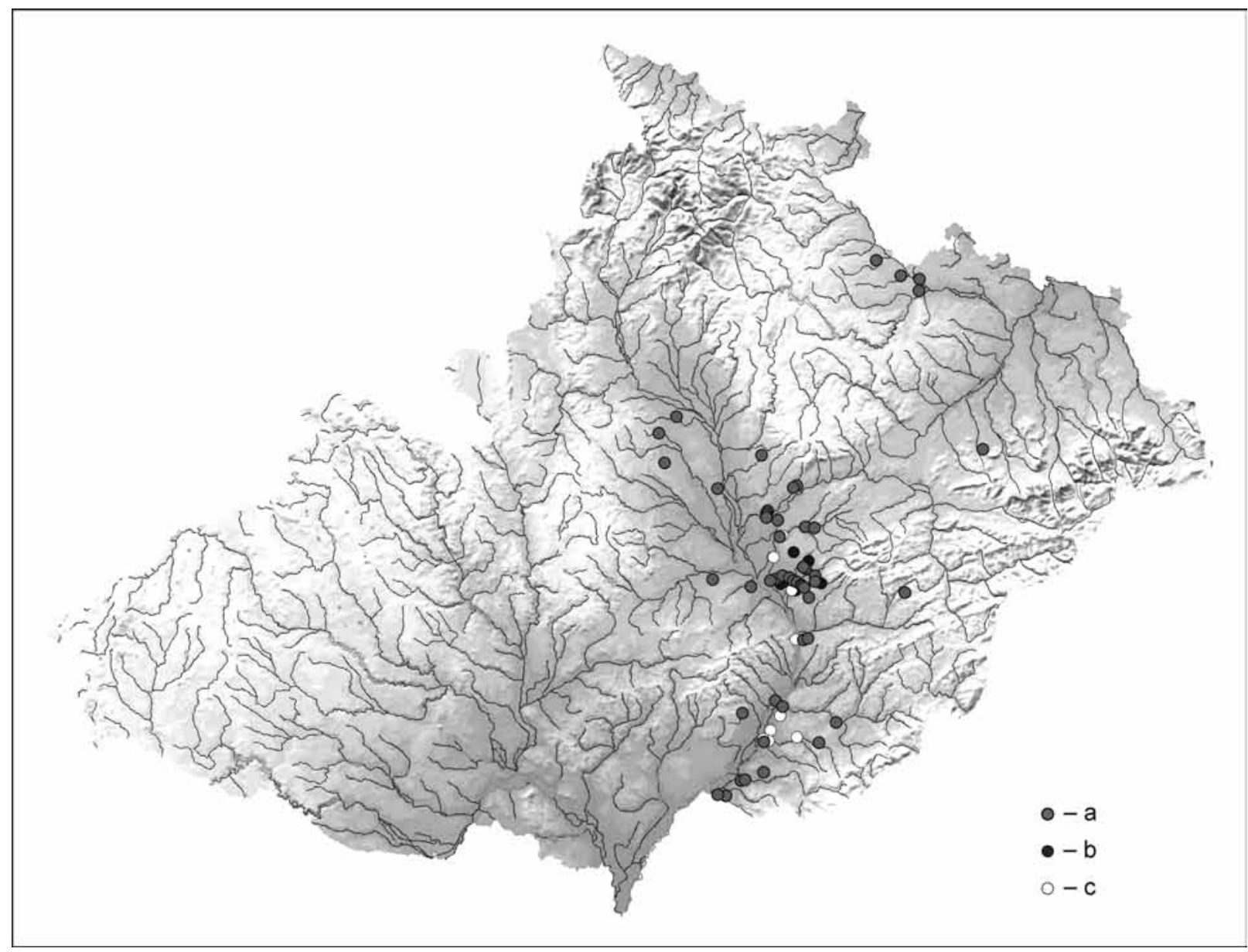

Obr. 2. Mapa osídlení nitranskou kulturou, s neverifikovanými lokalitami podle Kolbinger 2012 (Hulín-Ve vysokém trní, Hulín-Višňovce, Kunovice, Ludslavice, Martinice, Němčice, Pravčice-Křtěnce a Klíny, Roštín 2 lokality) a neklasifikované z únětické kultury (Horní Moštěnice, Chrášt’any, Kunovice, Kunovice-Hluk, Napajedla, Ostrožská Nová Ves, Ostrožské Předměstí, Uherský Brod, Žalkovice). Legenda: a - nitranská kultura; b - neverifikované lokality; c - únětická kultura.

sídlišt' (Peška/Tajer 2015a; 2015b), kulturních vlivů a kontaktů (Peška 2013), souborné zhodnocení EPKK na Moravě a ve Slezsku, včetně vyjasnění terminologie, vnitřní periodizace nebo relativní a absolutní chronologie entity dosud postrádáme.

Posuzujeme-li EPKK (dřívější skupina/kultura Chłopice-Veselé a nitranská kultura) jako kompaktní jednotku, evidujeme dnes na Moravě (a v příslušné části Slezska) 54 lokalit (obr. 1). Více než polovinu ( $53,7 \%$ ) představují kostrová pohřebiště nebo jednotlivé hroby, 13 poloh (24,07 \%) lze označit za sídliště a stejné hodnoty $(24,07 \%)$ dosahují povrchové sběry nebo ojedinělé nálezy typické keramiky. V minoritě (shodně 1,85 \%) jsou solitérní nálezy měděné industrie (vrbový list z Vitčic) a broušené industrie (sekeromlat ze Všeminy), u kterých je však (bez typických atributů) velice obtížné stanovit kulturní př́slušnost. Epišňůrové předměty z povrchových sběrů $\mathrm{D}$. Kolbingera bude nutno ještě verifikovat (Kolbinger 2012) jak po stránce alokace, tak také chronologického zařazení. Ze zatímního pohledu se zdá, že asi devět lokalit by mohlo být "nových“ (obr. 2).

Kromě výše uvedeného je $z$ území na východ od řeky Moravy evidována celá řada nálezů a nalezišt’ (většinou hrobů: Žalkovice, Horní Moštěnice, Napajedla, Kunovice, Kunovice-Hluk, Ostrožská Nová Ves, Ostrožské Předměstí, Uherský Brod, Chráštany 1 a další) řazených tradičně pod únětickou kulturu (cf. Peška 1983; 1989; Stuchlík 2000; 2001; Tihelka 1953, 288 nn.), i když na základě výbavy (s výjimkou keramiky) by vlastně měly náležet rovněž do epišňưrové oikumeny. U chronologicky starších (BA1) tak mimochodem nastolují otázku přítomnosti ,"čisté“ únětické kultury (ÚK) v tomto prostoru, zvláště s ohledem na odkryvy nitranských sídlišt'. Pravdou však zůstává, že na východní Moravě se objevují jak sídliště se smíšeným nitransko-únětickým materiálem (Osek nad Bečvou 1), tak i lokality ze staršího období únětické kultury s nálezy čistě 
únětickými, kde jakákoliv přítomnost epišňůrového elementu chybí (Kunovice-Abrhámova, Knížecí cihelna, Napajedla, Ostrožské Předměstí, Uherský Brod-Šaňákova cihelna). Kulturní prúslušnost je lépe diagnostikovatelná u hrobů, přitom určitá míra vzájemných vazeb obou komponent (pohřebiště a sídliště) by $\mathrm{k}$ dispozici byla (nálezy obou kultur na stejném katastru, ne-li ze stejných poloh). Je tak zřejmé, že se touto otázkou bude zapotřebí ještě zabývat.

Model tehdejší struktury osídlení si lze dobře představit např́klad na katastru Hulína, kde je dosavadní badatelskou činností (intenzivní mnohaleté povrchové prospekce $D$. Kolbingera a výzkumy Archeologického centra Olomouc od roku 2004: Berkovec/Peška 2005a; 2006; Kolbinger 2012; Tajer 2009) zachycená hustá sít (dosud 7 poloh) epišňưrových nalezišt’ (Peška 2016; Peška/Tajer 2015a). Teoretickým transferem podoby osídlení na zbytek, resp. přijatelné části východní Moravy a Slezska získáme charakter sídelní struktury EPKK a její intenzity. Pokud bychom akceptovali přiřazení všech „nových“ poloh D. Kolbingera a také přehodnocení kulturní př́islušnosti staroúnětických pohřebišṫ (viz výše), stoupl by počet epišňůrových lokalit na číslo 72 (obr. 2) s ještě výraznějším podílem pohřební komponenty. Těsná návaznost osídlení obou kulturních jednotek v Pomoraví je zřejmá, stejně jako slabší pruh epišňůrového osídlení podél pravého břehu řeky Moravy (Peškal Tajer 2015a, obr. 3), ačkoliv přesnou hraniční čáru sídelní oikumeny stanovit nelze, osídlení se patrně $\mathrm{v}$ poklidném duchu prolínalo.

\section{HISTORIE VÝZKUMU A TERMINOLOGIE}

Epišňůrový přikarpatský kulturní komplex jako okruh především již starobronzových kultur Mierzanowice - Nitra - Koštany byl vyčleněn J. Machnikem (1967) na širším území severně a jižně Karpat. Tomu předcházela (i terminologická) geneze skupiny, později kultury Chłopice-Veselé (Machnik 1960, 55; 1963, 67; 1977), vyčleněné z pozdně šňůrových skupin, avšak nejdříve spojované se šňurovou keramikou typu Złota (Buchvaldek 1963). V téže době na základě nálezů ze sídliště v malopolských Chłopicích a z pohřebiště ve Veselém vyčlenil J. Machnik skupinu Chłopice-Veselé a na Slovensku tutéž skupinu památek označil A. Točík (1963) jako typ Veselé. Zlomovým bodem byla publikace výzkumu pohřebiště ve Veselém (Budinský-Krička 1965), kde autor správně poukázal na podobnost s nálezy ze západní Ukrajiny, které I. K. Svešnikov (1974, 80-117) označil za kulturu Gorodk-Zdovbicja. Později byla skupina Chłopice-Veselé uznána za kulturu (Machnik 1977, 29) a stala se základem EPKK.

Na počátku devadesátých let 20. stol. polští vědci na základě stratigrafie a radiouhlíkových dat z lokality Iwanowice-Babia Góra prokázali, že se $\mathrm{v}$ př́ípadě kultury Chłopice-Veselé jedná vlastně o dva časové horizonty, a vyčlenili starší protomierzanovický (materiál typu Chłopice) a mladší časně mierzanovický horizont (materiál typu Veselé; Kadrow/Machnikowie 1992, 90-93), což bylo přijato pouze částí badatelů (cf. Bátora 2000; Kadrow/Peška 1999; Kadrow/Peška/Vitula 2000) s tím, že v rámci EPKK ji např́klad J. Bátora $(2000,517)$ považuje za protonitranskou fázi nitranské kultury a na východním Slovensku za protokoštanskou fázi koštanské kultury a de facto s pojmem kultura Chłopice-Veselé pracuje zmíněný autor dodnes, zahrnujíce pod tento termín počáteční fáze velkých pohřebišt na JZ Slovensku (naposled Bátora 2018, 71 n.). Z. Benkovsky-Pivovarová (1999) na základě vymapování hrnkủ zdobených otisky šňůry vyčleňuje bezejmennou skupinu EPKK na východní Moravě a na západním Slovensku, která je od nitranské kultury v Ponitř́i odlišná, později navrhuje označení moravsko-západoslovenská skupina nitranské kultury (Benkovsky-PivovaroválChropovský 2015, 116). Ačkoliv si uvědomujeme jisté regionální rozdíly epišňưrového materiálu, rostoucí přímo úměrně se vzdáleností od „krystalizačního jádra“ kultury, vydělování regionálních skupin nepovažujeme za vhodné, nebot' se tímto způsobem projevuje celá řada kulturních jednotek. V rámci nitranské kultury existuje více shodných rysů než rozdílů a ve srovnání například s únětickou kulturou na Slovensku, Moravě, v Čechách, Polsku nebo Německu bychom v ní našli daleko více a větších odlišností než ve vlastní nitranské kultuře. Tam, kde je to jen trochu možné a smysluplné, zkusme zachovávat v označování kultur terminologickou jednotu.

Nitranská kultura byla vyčleněna na základě koncentrace pohřebišt’ v údolí řeky Nitry $A$. Točíkem (1956, 24-46), kvalitativní skok v poznání entity znamenala jeho studie z roku 1963, kde autor používá pojmu nitranská skupina (Točík 1963). V téže době publikuje několik moravských nálezů J. Ondráček (1963) a používá pro ně označení nálezy mierzanovicko-nitranského typu, později epišnưorové památky označuje za skupinu, a to i při hodnocení největšího pohřebiště v Holešově a syntézy v rámci Pravěkých dějin Moravy (Ondráček 1972; 1993; Ondráček/Šebela 1985). Terminologická nejednotnost je na Slovensku ustálena v době vydání Slovenska v dobe bronzovej, kde se autoři definitivně přiklánějí k označení nitranská kultura (Furmánek/Veliačik/Vladár 1991, 51-53). Nejasnosti, týkající se však vnitřního uspořádání mierzanovic- 
ké kultury v Malopolsku, se podařilo definitivně rozptýlit v monografickém vyhodnocení (Kadrow/ Machnik 1997), kde se autoři přiklonili ke čtyřfázovému členění kultury (proto-, časně-, klasická a pozdní mierzanovická kultura). V zajetí starší terminologie zůstávají i někteří moravští badatelé (Stuchlík 2014, 40, 41).

\section{Dosavadní členění EPKK}

Terminologická nejednotnost, různé náhledy a názory na pozici obou výrazných složek, tvořících pevnou součást celého epišňưrového komple$\mathrm{xu}$, ale hlavně na Moravě absence jasně definované vnitřní periodizace tohoto okruhu památek nás vede k pokusu o její stanovení. Všichni specialisté se shodují v tom, že základním kamenem epišňůrového komplexu jsou nálezy dříve označované jako typ/skupina/kultura Chłopice-Veselé, které však, jak prokázali polští kolegové, nevykazují totožnou chronologickou pozici, a proto je nutno od tohoto spojení ustoupit. Označení pojmu „epišňůrový“ (nález, hrob, sídliště etc.) je př́liš obecný a není z něj zřejmé, jak přesně staré kontexty jsou myšleny. Již dříve bylo nasnadě, že nálezy Chłopice-Veselé jsou vlastně jen nejstarším projevem onoho komplexu, a že je lze vnímat jako první fázi/fáze pozdější nitranské kultury (Peška 1989, 197; Peška/Šebela 1992, 140), podobně jako je tomu v př́padě platného členění mierzanovické kultury v Malopolsku nebo jako v prípadě vztahu protoúnětické a únětické kultury na Moravě (Peška 2009). S interní periodizací mierzanovické kultury, díky bohatým nálezům z malopolských nalezišt', větší problémy nemáme, zdá se být věrohodná a podle všeho bude aplikovatelná i na Horní Slezsko, včetně jeho jižní části (viz dále). $A$. Točík (1963) ve své studii k nitranské skupině tuto dělí na dva horizonty, $\mathrm{z}$ nichž ve starším dominuje industrie ve tvaru vrbového listu a v mladším drátěný šperk a triangulární dýky. Později (Točík 1979, 12) nitranskou kulturu člení na:

- starší - pohřebiště Ivanka pri Dunaji a začátky pohřbívání ve Výčapech-Opatovcích, Branči a Holešově, (na jiném místě označena jako proto-, resp. časně nitranská fáze: Točík 1979, 26);

- klasická - převážná část hrobů na jmenovaných pohřebištích, mladší fáze je přechodná s rysy III. a IV. stupně únětické kultury, končí VýčapyOpatovce a začíná Vel'ký Grob a Hurbanovo.

Na něj navázal J. Bátora při vyhodnocování pohřebiště z Jelšovec (Bátora 2000, 517) a rozdělil nitranskou kulturu na tři fáze (časná, klasická a pozdní - přechodná nitransko-únětická), které ztotožňuje se třemi horizonty Reineckeho stupně BA1a-c. Jim předchází kultura Chłopice-Veselé, označená jako protonitranská, vyplňující stupeň A0. V pozdějších pracích považuje nejstarší horizont nitranských pohřebište za vyznívání kultury Chłopice-Veselé s označením „horizont Chłopice-Veselé - Nitra" (Bátora 2018, 51; Bátora/Vladár 2015, 23). Pokusy o členění nejstarších nitranských nálezů se objevily na Slovensku (Lichardus/Vladár 1997) a také nověji Z. Benkovsky-Pivovarová naznačuje chronologické rozdíly mezi nálezy, považujíce keramiku z Cífera-Páce a z Ivanky pri Dunaji za nejstarší na úrovni moravské EPKK I (Benkovsky-Pivovarovál Chropovský 2015, 13). Naopak, J. Bátora (2018, 75; Bátora/Vladár 2015,23) ve svých posledních pracích člení kulturu Chłopice-Veselé na starší (Veselé, Čataj) a mladší (Ivanka pri Dunaji a Cífer-Pác). Můžeme-li soudit na základě srovnání $\mathrm{s}$ malopolským materiálem, zařadili bychom materiál z JZ Slovenska skutečně už do časné fáze mierzanovické kultury ve smyslu malopolské chronologie. Jako vůbec nejstarší nález ještě na úrovni protomierzanovické se nám jeví keramika (hrnek tektonikou připomínající průvodní keramiku zvoncovitých pohárů a střep z výduti, obojí zdobeno horizontálními a vertikálními násobnými liniemi otisků šňůry) z lokality Kúty II (Benkovsky-Pivovarová/Chropovský 2015, tab. 51: C), která však může souviset spíše s Moravou (ostatně jako celá oblast západně od Malých Karpat) než s vlastním JZ Slovenskem (Pováží, Ponitří). Na Slovensku jsou k dispozici stovky až tisíce hrobů nitranské kultury, které by bylo záhodno do budoucna podrobit statistické analýze pro možnost srovnání výsledků a konec koncủ i správnosti nově navrhované interní periodizace. Handicapem je dosud nepublikovaná nekropole Ludanice-Mýtná Nová Ves (kolem 500 hrobů) a na Moravě nevyhodnocení Holešova a nezveřejnění pohřebiště z Hroznové Lhoty (115 hrobů), řada tematických článků zveřejněna byla (viz výše) a např́klad pohřebiště v Hulíně 3 (přes 100 hrobů) vykázalo tak chudý inventářr, že do statistických hodnocení nemůže vážněji zasáhnout.

Dosavadní pokusy o členění epišňurového období na Moravě vycházely z dosud publikovaných hrobových celků (Kadrow/Peška 1999, tab. 1; Peškal Šebela 1992, obr. 6) a zejména paralel v mierzanovické kultuře, bez dat absolutní chronologie. Prokázat se podařilo existenci epišňůrového elementu již od nejstarších fází (proto- a časná mierzanovická) s pozdějším zahájením pohřbívání $\mathrm{v}$ Holešově (EPKK IIb). S výjimkou Holešova a nepublikovaného pohřebiště z Hroznové Lhoty jsou epišňưrové pohřby na Moravě i na moravskoslezském pomezí vesměs velice chudé, což snižuje vypovídací hodnotu kontextů. 


\begin{tabular}{|c|c|c|c|c|c|c|}
\hline Artefakty/pohřební horizont & 1. & 2. & 3. & 4. & 5. & 6. \\
\hline \multicolumn{7}{|l|}{ Kostěnné korálky } \\
\hline \multicolumn{7}{|l|}{ Fajáns } \\
\hline \multicolumn{7}{|l|}{ Perlet' } \\
\hline \multicolumn{7}{|l|}{ Dentalium } \\
\hline \multicolumn{7}{|l|}{ Zviřeci žebra } \\
\hline \multicolumn{7}{|l|}{ Kanči kel } \\
\hline \multicolumn{7}{|l|}{ Šipka } \\
\hline \multicolumn{7}{|l|}{ Nátepní destička } \\
\hline \multicolumn{7}{|l|}{ Spirálovitá trubička } \\
\hline \multicolumn{7}{|l|}{ Náramek s přeloženými konci } \\
\hline \multicolumn{7}{|l|}{ Vrbový list hladký } \\
\hline \multicolumn{7}{|l|}{ Vrbový list se žebrem } \\
\hline \multicolumn{7}{|l|}{ Dvojitý drát } \\
\hline \multicolumn{7}{|l|}{ Dvojitý drát se smyčkou } \\
\hline Tyčinkovitý náramek & & & --- & & & \\
\hline Profilovaný hrnek & & & & & & \\
\hline
\end{tabular}

Obr. 3. Holešov-Zdražilovsko. Frekvence výskytu významných hrobových nálezů v jednotlivých pohřebních horizontech na pohřebišti nitranské kultury.

Podle J. Bátory (2000, 512-514) lze jednotlivé fáze nitranské kultury charakterizovat následovně:

- Časná fáze (navazuje na protonitranskou fázi = Chłopice-Veselé) keramika s otisky šňůry, lištami, vypíchaným ornamentem, mísy se zataženým okrajem a esovitě profilované mísy, industrie ve tvaru vrbového listu, ozdoby z dvojitého drátu bez zpětné smyčky, Noppenringy (?), drátěné nákrčníky, náramky se zahrocenými nebo přesahujícími se konci, šipky, nátepní destičky, kostěné trubice, korálky, kostěné jehlice s profilovanou hlavicí.

- Klasická fáze - (starší úsek a) vysoké hrnce a mísy, šperk ve tvaru vrbového listu, roste počet dýk (i zdobené), nože, oboustranná šídla, kostěné jehlice s profilovanou a terčovitou hlavicí, kančí kly, kostěné korálky, kostěné rozdělovače, fajánsové korálky; (mladší úsek b) esovitě profilované hrnce a hrnky, vrbový list s výrazným středovým žebrem, jednoduchý a dvojitý drát se smyčkou i bez, kostěné jehlice s kyjovitou a lopatkovitou hlavicí, vrcholí kostěné korálky, rozdělovače, perletové korálky, mušle.

- Pozdní fáze (nitransko-únětická) přežívání artefaktů nitranské a nástup nových z prostředí únětické kultury, nezdobené i zdobené jehlice s terčovitou hlavicí, plechové diadémy, spirálovité trubičky, dentalium, členěné fajánsové korálky, nátepní destičky (?), vrbový list se žebrem, dvojitý drát se zpětnou smyčkou, spirálovité náramky, drátěný nákrčník, plechové trubičky, kostěné korálky a rozdělovače.

\section{POHŘEBNÍ HORIZONTY V HOLEŠOVĚ}

Sledováním vzájemné korelace hrobové výbavy $\mathrm{v}$ Holešově jsme dospěli $\mathrm{k}$ některým dílčím zjištěním, byt๋ většina hrobových přídavků má nevelký chronologický potenciál. J. Ondráček zde rozlišil tři časové úseky. Nejstarší koresponduje s dřívější skupinou/kulturou Chłopice-Veselé (nepř́lilš výrazný inventář: hrnky s otisky šňưry, kostěné válcovité korálky, ozdoby ve tvaru vrbového listu), střední pak představuje běžnou výbavu s kovovými dýkami, drátěným šperkem, jehlicemi, vlasovými ozdobami, korálky z různých surovin a keramikou z prostředí starší a předklasické únětické kultury. V nejmladším období se $\mathrm{v}$ hrobech objevují artefakty z klasické fáze únětické kultury na východním a jižním okraji nekropole (Ondráček 1972, 170, 171). Pohřbívání začíná dříve než v Jelšovcích, zhruba na úrovni nekropole ve Veselém (časná mierzanovická kultura) a končí na úrovni klasické únětické kultury. $\mathrm{V}$ tomto období jsme schopni stanovit celkem šest horizontů pohřbívání v Holešově (obr. 3), jako na jediné podrobněji hodnotitelné lokalitě na východní Moravě. Z předběžných pozorování vyplývá možnost vyčlenění nejstaršího horizontu (1) s lehce esovitě profilovanými hrnky zdobenými svazky nebo řadami otisků šňůry, artefakty ve tvaru vrbového listu a kostěnými válcovitými korálky. Se zařazením ještě do tohoto nebo už následného horizontu (2) váháme $u$ keramiky 
zdobené horizontálními liniemi a svazky šňůry, avšak na tvarech typologicky neznámých (H 381: Ondráček/Šebela 1985, tab. 34: 13). Hroby s nátepními destičkami, šipkami nebo kančími kly, doprovázenými vrbovým listem hladkým i se žebrem, zvírecími žebry, štípanou industrií etc. mohou patřit stejně dobře do přechodného období mezi nejstarším a starším horizontem pohřbívání v Holešově (Bátorův horizont Chłopice-Veselé Nitra), ale stejně tak starší nitranské kultuře (horizont 3). Pozorujeme v podstatě jen minimální rozdíl mezi výskytem předmětů ve tvaru vrbového listu hladkými a se žebrem, které často vystupují spolu (v Holešově jistý rozdíl patrný je, ve statistice prakticky nikoliv). Sledujeme poměrně brzký nástup drátěné industrie, včetně vlasových ozdob z dvojitého drátu se zpětnou smyčkou (objevující se opakovaně s hladkým vrbovým listem) a také výskyt korálků, resp. náhrdelníků s různými druhy korálků nelze od sebe spolehlivě časově oddělit (starší kostěné válcovité a fajánsové, mladší patrně perletové a dentalium, obecně ale dost průběžné). Pokračující vývoj vrbového listu a nárůst drátěné industrie, ploché triangulární dýky, plechové trubičky a zahnuté plíšky, šipky, početná štípaná industrie, ale také nástroje z kostí a parohu (kladivo, motyka, sekeromlat), zvírecí žebra, společně se všemi druhy korálků a svébytnou keramikou, to jsou milodary příznačné pro typické nitranské hroby (4. horizont). Do jejího nejmladšího (pozdního) stadia řadíme pohřby doprovázené výlučně drátěnými šperky, plechovou čelenkou, terčovitou jehlicí a předklasickou únětickou keramikou (horizont 5). Poslední (6) horizont ukládání hrobů v Holešově náleží již plně zformované klasické únětické kultuře, kde se zcela vytratila původní nitranská forma přídavků, pohřební ritus však zůstává epišňůrový a biologicky půjde s velkou pravděpodobností o tentýž lid.

\section{ORDINACE INCIDENČNÍ MATICE A SROVNÁNÍS ABSOLUTNÍMI DATY}

Pro kvantifikaci a zobrazení naší koncepce jsme zvolili srovnání několika nezávislých metod mnohorozměrné statistiky jako je korespondenční analýza (CA), analýza hlavních komponent (PCA), analýza hlavních koordinát (PCO), seriace a korelace mezi provedenými ordinačními a seriačními analýzami. V neposlední řadě byl učiněn pokus korelace výsledků ordinačních analýz s dostupnými absolutními daty. Užíváme především statistické termíny používané $\mathrm{v}$ učebnici statistických metod editované J. Holčíkem a M. Komendou (2015), postupy ovšem respektují původní metody a jejich implementaci v níže uvedených programech/balíčcích pro statistický program $\mathrm{R}$.

\section{CÍLE A POSTUP}

Cílem bylo $\mathrm{v}$ mnohorozměrné struktuře dat - hrobových př́idavků - najít směr, který nese chronologický význam a interpretovat jeho obsah. Vzhledem ke škále předmětů, které jsou v hrobech nalézány, od kultovně podmíněné standardizované hrobové výbavy s neznámými ideologickými konotacemi, až k osobním předmětům a oděvu, a vzhledem $\mathrm{k}$ různým sociálním nehomogenitám $\mathrm{v}$ datech (bohaté vs. chudé hroby, muži vs. ženy, mladší vs. starší věkové skupiny aj.) na straně jedné a relativně krátkému období v prehistorii na straně druhé, nebylo možné očekávat, že právě největší variabilita $\mathrm{v}$ datech ponese časový signál. Základní postup tedy spočíval v tom, že jsme provedli ordinační (popisnou, pořádací) analýzu dat hrobové výbavy, která rozdělila variabilitu $\mathrm{v}$ datech sestupně od největší po nejmenší komponentu podle jejich podílu vyčerpané variance, a následně jsme mezi vyššími komponentami z ordinačních metod hledali ty, které nejsilněji korelovaly s absolutními chronologickými daty $\left(\mathrm{C}^{14}\right)$, získanými pro malou podskupinu hrobových celků (celkem 23 absolutních dat; tabela 1$)$. $K$ výpočtům jsme použili rutiny dostupné v programu PAST (Hammerl Harper/Ryan 2001), programu R (R Core Team 2019) a v jeho doplňujících balíčcích (Lê/Josse/Husson 2008; Wei/Simko 2017; Wickham 2016).

\section{POPIS ORDINAČNÍCH METOD ZPRACOVÁNÍ}

Základem analýzy byla incidenční matice (přítomnost kódována jako 1 , nepř́tomnost jako 0) výskytu 59 předmětů (proměnných) nalezených ve 415 hrobech (př́ipadech, tj. řádcích matice), což představuje celkem 24485 hodnot. $Z$ nich ovšem pouze 875 obsahovalo hodnotu 1 (př́tomnost), tj. $3,57 \%$, zbytek představují nepř́ítomnosti. Jde tedy o matici celkově př́tomností řídkou, což může znamenat, že i některé malé rozdíly a výjimečné př́pady mohou mít relativně velký vliv na celkovou ordinaci. Odlišnosti př́padů tedy mohou být poměrně značné a pak nelze předpokládat, že se většinu variability podaří extrahovat do několika prvních komponent.

Vzhledem $\mathrm{k}$ povaze dat jsme zvolili několik ordinačních metod, které představují principiální 
Tabela 1. Nitranská kultura na Moravě a ve Slezsku. Výběr absolutních dat sloužících k nezávislé verifikaci. OxCal program v.4.4.2.

\begin{tabular}{|c|c|c|c|c|}
\hline Lokalita & Laboratoř & BP & 1 sigma & 2 sigma \\
\hline Holesov Gr. 46 & VERA 3369 & $3610 \pm 45$ & $\begin{array}{c}2028 \text { BC }(63,7 \%) 1919 \text { BC } \\
1911 \text { BC }(4,6 \%) 1901 \text { BC }\end{array}$ & $\begin{array}{c}2135 \mathrm{BC}(9,7 \%) 2080 \mathrm{BC} \\
2062 \mathrm{BC}(83,4 \%) 1878 \mathrm{BC} \\
1841 \mathrm{BC}(1,8 \%) 1824 \mathrm{BC} \\
1791 \mathrm{BC}(0,7 \%) 1782 \mathrm{BC}\end{array}$ \\
\hline Holesov Gr. 78 & VERA 3371 & $3555 \pm 35$ & $\begin{array}{c}1950 \mathrm{BC}(54,0 \%) 1878 \mathrm{BC} \\
1841 \mathrm{BC}(9,3 \%) 1824 \mathrm{BC} \\
1792 \mathrm{BC}(5,0 \%) 1781 \mathrm{BC}\end{array}$ & $\begin{array}{c}2021 \mathrm{BC}(4,9 \%) 1994 \mathrm{BC} \\
1980 \mathrm{BC}(63,3 \%) 1866 \mathrm{BC} \\
1851 \mathrm{BC}(27,2 \%) 1770 \mathrm{BC}\end{array}$ \\
\hline Holesov Gr. 83 & VERA-3372 & $3420 \pm 35$ & $\begin{array}{c}1764 \mathrm{BC}(2,1 \%) 1760 \mathrm{BC} \\
1751 \mathrm{BC}(54,5 \%) 1668 \mathrm{BC} \\
1656 \mathrm{BC}(11,7 \%) 1634 \mathrm{BC}\end{array}$ & $\begin{array}{c}1875 \mathrm{BC}(9,3 \%) 1843 \mathrm{BC} \\
1820 \mathrm{BC}(3,6 \%) 1798 \mathrm{BC} \\
1778 \mathrm{BC}(82,6 \%) 1620 \mathrm{BC}\end{array}$ \\
\hline Holesov Gr. 84 & VERA 3373 & $3625 \pm 45$ & $\begin{array}{c}2113 \mathrm{BC}(4,6 \%) 2100 \mathrm{BC} \\
2036 \mathrm{BC}(63,7 \%) 1925 \mathrm{BC}\end{array}$ & $2136 \mathrm{BC}(95,4 \%) 1884 \mathrm{BC}$ \\
\hline Holesov Gr. 91 & VERA 3374 & $3650 \pm 50$ & $\begin{array}{l}2132 \mathrm{BC}(19,8 \%) 2086 \mathrm{BC} \\
2048 \mathrm{BC}(48,5 \%) 1946 \mathrm{BC}\end{array}$ & $\begin{array}{r}2194 \mathrm{BC}(2,2 \%) 2176 \mathrm{BC} \\
2144 \mathrm{BC}(93,3 \%) 1891 \mathrm{BC}\end{array}$ \\
\hline Hulin 1-U Isidorka Gr. 16 & Poz-15057 & $3500 \pm 35$ & $\begin{array}{l}1884 \mathrm{BC}(12,2 \%) 1864 \mathrm{BC} \\
1853 \mathrm{BC}(56,1 \%) 1768 \mathrm{BC}\end{array}$ & $\begin{array}{c}1924 \mathrm{BC}(93,6 \%) 1740 \mathrm{BC} \\
1710 \mathrm{BC}(1,8 \%) 1699 \mathrm{BC}\end{array}$ \\
\hline Hulin 1-U Isidorka Gr. 56 & KIA 34680 & $3560 \pm 30$ & $\begin{array}{c}1952 \mathrm{BC}(61,9 \%) 1879 \mathrm{BC} \\
1839 \mathrm{BC}(6,4 \%) 1826 \mathrm{BC}\end{array}$ & $\begin{array}{c}2020 \mathrm{BC}(4,7 \%) 1996 \mathrm{BC} \\
1980 \mathrm{BC}(71,2 \%) 1872 \mathrm{BC} \\
1848 \mathrm{BC}(11,5 \%) 1812 \mathrm{BC} \\
1806 \mathrm{BC}(8,0 \%) 1774 \mathrm{BC}\end{array}$ \\
\hline Hulin 1-U Isidorka Gr. 65 & KIA 34681 & $3625 \pm 25$ & 2026 BC $(68,3 \%) 1948$ BC & $\begin{array}{c}2120 \mathrm{BC}(4,8 \%) 2096 \mathrm{BC} \\
2039 \mathrm{BC}(90,6 \%) 1898 \mathrm{BC}\end{array}$ \\
\hline Hulin 1-U Isidorka Gr. 65a & KIA 34682 & $3675 \pm 30$ & $\begin{array}{c}2134 \mathrm{BC}(37,0 \%) 2080 \mathrm{BC} \\
2061 \mathrm{BC}(24,0 \%) 2021 \mathrm{BC} \\
1994 \mathrm{BC}(7,2 \%) 1981 \mathrm{BC}\end{array}$ & $2141 \mathrm{BC}(95,4 \%) 1956 \mathrm{BC}$ \\
\hline Hulin 1-U Isidorka Gr. 69 & KIA 34683 & $3685 \pm 25$ & $\begin{array}{l}2134 \mathrm{BC}(44,6 \%) 2080 \mathrm{BC} \\
2061 \mathrm{BC}(23,7 \%) 2030 \mathrm{BC}\end{array}$ & $\begin{array}{c}2192 \mathrm{BC}(2,2 \%) 2179 \mathrm{BC} \\
2144 \mathrm{BC}(86,4 \%) 2014 \mathrm{BC} \\
2000 \mathrm{BC}(6,9 \%) 1976 \mathrm{BC}\end{array}$ \\
\hline Hulin 1-U Isidorka Gr. 71 & KIA 34684 & $3625 \pm 25$ & $2026 \mathrm{BC}(68,3 \%) 1948 \mathrm{BC}$ & $\begin{array}{c}2120 \mathrm{BC}(4,8 \%) 2096 \mathrm{BC} \\
2039 \mathrm{BC}(90,6 \%) 1898 \mathrm{BC}\end{array}$ \\
\hline Hulin 1-U Isidorka Gr. 76 & KIA 34685 & $3585 \pm 25$ & $\begin{array}{c}2008 \mathrm{BC}(1,9 \%) 2004 \mathrm{BC} \\
1968 \mathrm{BC}(1,9 \%) 1966 \mathrm{BC} \\
1960 \mathrm{BC}(64,4 \%) 1892 \mathrm{BC}\end{array}$ & $\begin{array}{c}2026 \mathrm{BC}(14,2 \%) 1991 \mathrm{BC} \\
1985 \mathrm{BC}(80,3 \%) 1881 \mathrm{BC} \\
1836 \mathrm{BC}(0,9 \%) 1830 \mathrm{BC}\end{array}$ \\
\hline Hulin 3-U potucku Gr. 4 & Poz-14859 & $3640 \pm 35$ & $\begin{array}{c}2116 \mathrm{BC}(8,1 \%) 2099 \mathrm{BC} \\
2037 \mathrm{BC}(60,2 \%) 1948 \mathrm{BC}\end{array}$ & $\begin{array}{l}2135 \mathrm{BC}(19,4 \%) 2080 \mathrm{BC} \\
2061 \mathrm{BC}(76,0 \%) 1900 \mathrm{BC}\end{array}$ \\
\hline Hulin 3-U potucku Gr. 48 & Poz-14861 & $3620 \pm 35$ & $2031 \mathrm{BC}(68,3 \%) 1931 \mathrm{BC}$ & $\begin{array}{c}2130 \mathrm{BC}(8,8 \%) 2088 \mathrm{BC} \\
2046 \mathrm{BC}(86,6 \%) 1886 \mathrm{BC}\end{array}$ \\
\hline Hulin 3-U potucku Gr. 53 & Poz-14921 & $3560 \pm 40$ & $\begin{array}{c}1960 \mathrm{BC}(54,2 \%) 1876 \mathrm{BC} \\
1842 \mathrm{BC}(8,8 \%) 1823 \mathrm{BC} \\
1794 \mathrm{BC}(5,3 \%) 1780 \mathrm{BC}\end{array}$ & $\begin{array}{c}2026 \mathrm{BC}(8,1 \%) 1990 \mathrm{BC} \\
1986 \mathrm{BC}(62,5 \%) 1866 \mathrm{BC} \\
1852 \mathrm{BC}(24,8 \%) 1769 \mathrm{BC}\end{array}$ \\
\hline Hulin 3-U potucku Gr. 66 & Poz-14862 & $3620 \pm 30$ & 2027 BC (68,3 \%) 1941 BC & $\begin{array}{l}2123 \mathrm{BC}(5,6 \%) 2094 \mathrm{BC} \\
2040 \mathrm{BC}(89,8 \%) 1891 \mathrm{BC}\end{array}$ \\
\hline Hulin 3-U potucku Gr. 73 & Poz-14864 & $3490 \pm 35$ & $\begin{array}{c}1880 \mathrm{BC}(11,5 \%) 1862 \mathrm{BC} \\
1856 \mathrm{BC}(11,3 \%) 1838 \mathrm{BC} \\
1828 \mathrm{BC}(40,9 \%) 1766 \mathrm{BC} \\
1759 \mathrm{BC}(4,5 \%) 1751 \mathrm{BC}\end{array}$ & $\begin{array}{c}1920 \mathrm{BC}(0,9 \%) 1910 \mathrm{BC} \\
1902 \mathrm{BC}(90,1 \%) 1736 \mathrm{BC} \\
1716 \mathrm{BC}(4,4 \%) 1694 \mathrm{BC}\end{array}$ \\
\hline Opava-Vavrovice Gr. 17 & Poz-75435 & $3690 \pm 30$ & $\begin{array}{l}2136 \mathrm{BC}(43,5 \%) 2074 \mathrm{BC} \\
2068 \mathrm{BC}(24,8 \%) 2032 \mathrm{BC}\end{array}$ & $\begin{array}{c}2197 \mathrm{BC}(5,7 \%) 2170 \mathrm{BC} \\
2147 \mathrm{BC}(83,0 \%) 2012 \mathrm{BC} \\
2000 \mathrm{BC}(6,7 \%) 1974 \mathrm{BC}\end{array}$ \\
\hline Opava-Vavrovice Gr. 18 & Poz-85800 & $3540 \pm 30$ & $\begin{array}{l}1931 \mathrm{BC}(41,4 \%) 1876 \mathrm{BC} \\
1843 \mathrm{BC}(15,7 \%) 1822 \mathrm{BC} \\
1796 \mathrm{BC}(11,2 \%) 1778 \mathrm{BC}\end{array}$ & $\begin{array}{c}1958 \mathrm{BC}(94,8 \%) 1766 \mathrm{BC} \\
1758 \mathrm{BC}(0,6 \%) 1751 \mathrm{BC}\end{array}$ \\
\hline Osek nad Becvou 2 Gr. 1 & Poz-74493 & $3515 \pm 35$ & $\begin{array}{l}1893 \mathrm{BC}(15,7 \%) 1867 \mathrm{BC} \\
1850 \mathrm{BC}(52,6 \%) 1770 \mathrm{BC}\end{array}$ & $1939 \mathrm{BC}(95,4 \%) 1743 \mathrm{BC}$ \\
\hline Osek nad Becvou 2 Gr. 1 & Poz-74494 & $3575 \pm 35$ & $\begin{array}{l}2010 \mathrm{BC}(3,9 \%) 2002 \mathrm{BC} \\
1972 \mathrm{BC}(64,4 \%) 1884 \mathrm{BC}\end{array}$ & $\begin{array}{c}2030 \mathrm{BC}(84,7 \%) 1873 \mathrm{BC} \\
1846 \mathrm{BC}(6,5 \%) 1818 \mathrm{BC} \\
1802 \mathrm{BC}(4,3 \%) 1776 \mathrm{BC}\end{array}$ \\
\hline
\end{tabular}


Tabela 1. Pokračování.

\begin{tabular}{|c|c|c|c|c|}
\hline Lokalita & Laboratoř & BP & 1 sigma & 2 sigma \\
\hline Prerov-Predmosti 7 Gr.10 & DeA 18909 & $3762 \pm 32$ & $\begin{array}{c}2277 \mathrm{BC}(12,1 \%) 2254 \mathrm{BC} \\
2207 \mathrm{BC}(55,0 \%) 2136 \mathrm{BC} \\
2072 \mathrm{BC}(1,2 \%) 2070 \mathrm{BC}\end{array}$ & $\begin{array}{l}2288 \mathrm{BC}(81,1 \%) 2126 \mathrm{BC} \\
2092 \mathrm{BC}(14,3 \%) 2041 \mathrm{BC}\end{array}$ \\
\hline Prikazy Gr. & KIA 34744 & $3535 \pm 30$ & $\begin{array}{l}1926 \mathrm{BC}(35,8 \%) 1874 \mathrm{BC} \\
1844 \mathrm{BC}(18,2 \%) 1820 \mathrm{BC} \\
1798 \mathrm{BC}(14,3 \%) 1778 \mathrm{BC}\end{array}$ & $\begin{array}{c}1951 \mathrm{BC}(94,5 \%) 1764 \mathrm{BC} \\
1758 \mathrm{BC}(1,0 \%) 1750 \mathrm{BC}\end{array}$ \\
\hline
\end{tabular}

alternativy, operují s daty odlišným zpơsobem, a jejichž výsledky jsme následně srovnali.

První z ordinačních metod byla korespondenční analýza (CA), běžně používaná i v archeologii pro kontingenční matice výskytů, $v$ našem př́padě aplikovaná na matici incidenční (tj. počet pouze v rozsahu 0 a 1). Druhou ordinační metodou byla analýza hlavních komponent (PCA), která je navržena pro data kontinuálních proměnných, která ale někdy poskytuje relevantní výsledky i na kategoriálních číselně zadaných datech. Třetí ordinační metodou byla analýza hlavních koordinát (Principle Coordinates Analysis, PCO), kterou jsme aplikovali na matici podobností, vytvořenou na základě koeficientů podobnosti pro incidenční matice. $V$ našem prípadě jsme z obvykle používaných koeficientů použili index podobnosti (Raup/Crick 1979) dostupný v programu PAST (Hammer/Harper/Ryan 2001), který permutačně určuje míru podobnosti mezi dvěma př́pady srovnáním s podobnostmi s 1000 náhodně vybraných případů z celého souboru (tj. jakoby s rozložením podobností s ostatními), hodnoty podobností byly zesíleny transformačním exponentem 2. Čtvrtou metodou byla pak seriace (Brower) Kile 1988) v programu PAST (Hammer/Harper/Ryan 2001) v neomezeném (unconstrained) nastavení, řadící prrípady i proměnné tak, aby se přítomnosti (hodnoty 1) co nejvíce držely podél hlavní diagonály. Jejím výsledkem je tedy jedno pořadí hrobů a jedno pořadí předmětů $v$ nich.

Ve skóre jednotlivých komponent uvedených ordinačních metod a pořadí ze seriace jsme následně vybrali př́islušné hodnoty pro oněch 23 hrobů s dostupnými absolutními daty a jejich ordinační/ seriační hodnoty (skóre či pořadí) jsme pak korelovali se středními hodnotami jejich absolutních dat.

\section{VÝSLEDKY}

\section{Korespondenční analýza}

První korespondenční osa vyčerpala 4,5 \% celkové variance a byla plně dána pouze odlehlostí jediného případu (Slat-2) od zbytku souboru. Podobně druhá korespondenční osa (vyčerpala 3,7 \% varian- ce) představuje výrazně nerovnoměrné rozložení př́ipadů dané odlehlostí několika hrobů od jádra ostatních (od nejvzdálenějšího: skupina se stejnou hodnotou Slat-14, Hul1-79, Hol-231 a Hol-279, a další Hol-305, Slat-8, Hol-275, Hul1-71, Hol-66, Hol-273). Hrobové celky spojuje přitomnost esovitých misek (bez ucha i s uchem) nitranské produkce a náhrdelníků složených ze spirálovitých trubiček, které se však, například v Holešově, vyskytují i v hrobech klasické fáze únětické kultury. H 275 z Holešova (rourkovitá jehlice, měděný soudkovitý korál, vlasová ozdoba z dvojitého drátu s násobnou smyčkou, spirálovitá trubička) je řazen právě do klasické ÚK, př́slušnost ke skupině tak může být provázána právě přes onu spirálovitou trubičku.

Teprve třetí $(3,28 \%$ variance) a čtvrtá $(3,23 \%$ variance) korespondenční osa reprezentují relativně rovnoměrné a čitelné rozložení případů typického trojúhelníkovitého či podkovovitého tvaru mraku. Poměrně čitelné je vyčlenění nejmladších proměnných (koflík, osudí, rourkovitá jehlice, cyperská jehlice, Noppenring s násobnou smyčkou) na úrovni klasické ÚK s několika proměnnými (hrnky s otisky šňůry, hrncovitou mísou zdobenou šňůrou, kamenný sekeromlat) na druhé straně „podkovy“ spektra, které patři mezi nejstarší projevy EPKK, resp. NK. Blízko k nim má pomyslné druhé nejstarší seskupení nálezů v podobě nátepních destiček, šipek, dýky s výstupkem a broušená sekera. Do stejné (nebo podobné) skupiny nálezů patří hrnky protoúnětického charakteru, industrie ve tvaru vrbového listu a drátěné nákrčníky, stojící však nedaleko od reprezentantů spíše už mladšího vývojového stadia NK (plechový diadém, terčovitá jehlice, spirálovitý náramek, dvojitý drát a dvojitý drát se smyčkou). Podobně má svou jasnou pozici v blízkosti vyspělých únětických milodarů ostřeji profilovaná keramika (džbán, hrnky a již zmíněné spirálovité trubičky). Mrak uprostřed představuje jen obtížně rozlišitelný konglomerát proměnných patřící $\mathrm{k}$ průběžně se vyskytujícím milodarům v náplni NK s relativně dlouhou životností a nízkou chronologickou citlivostí. Za typické představitele můžeme považovat ozdoby $\mathrm{z}$ jednoduchého měděného drátu, zvířecí žebra, válcovité kostěné 


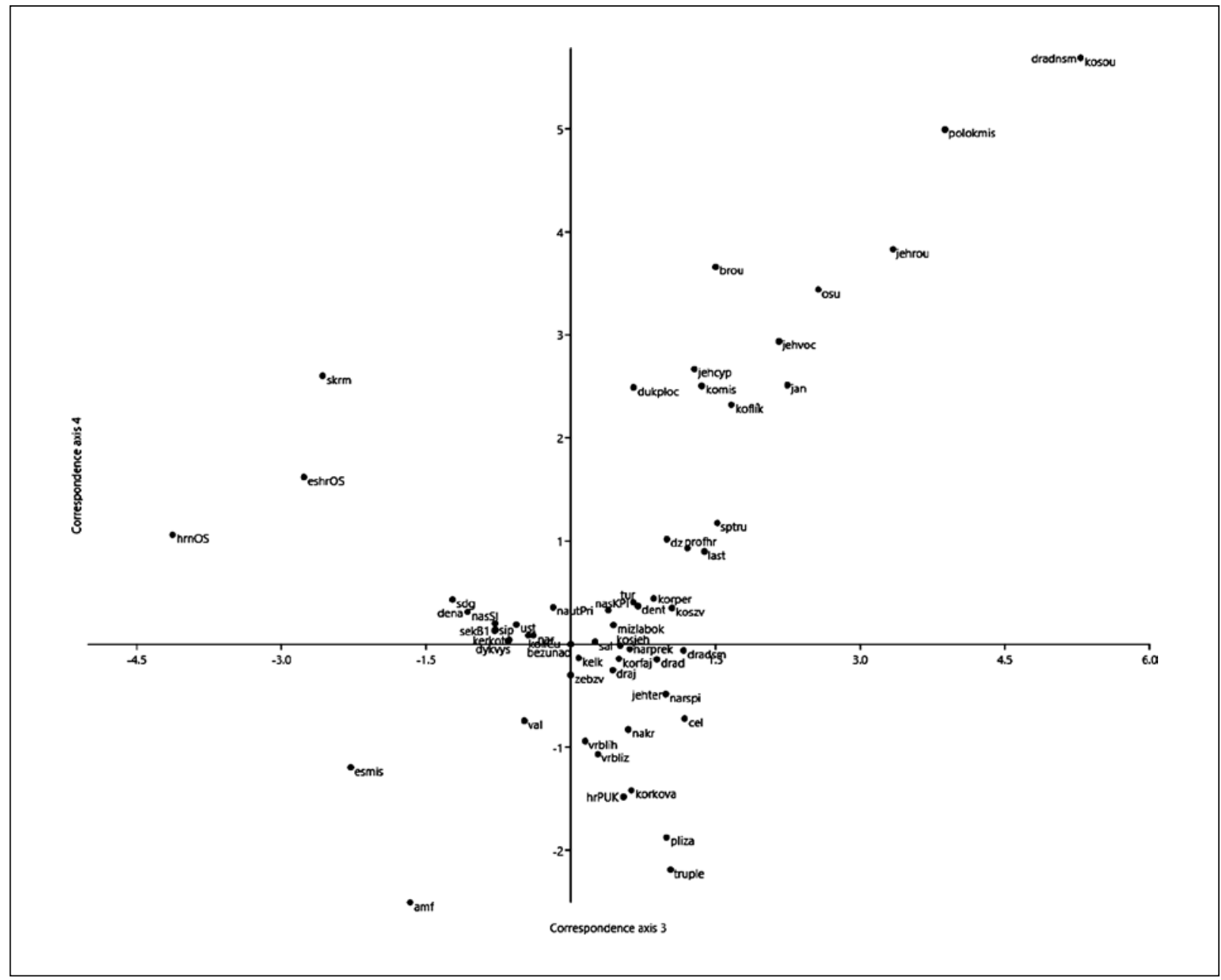

Obr. 4. Bodový graf skóre proměnných (hrobových nálezů) na korespondenčních osách 3 a 4 - výsledku korespondenční analýzy studované incidenční matice. Zkratky: hrnOS - hrncovitá nádoba s otisky šňůry; eshrOS - esovitý hrnek s otisky šňůry; amf - amfora; hrPUK - hrnek PÚK; esmis - esovitě profilovaná mísa; bezunad - bezuchá nádoba; polokmis polokulovitá mísa; mizlabok - mísa se žlábkem pod okrajem; dz - džbán; profhr - profilovaný hrnek; sal - šálek; koflík - koflík; osu - osudí; komis - kónická mísa; kerkot - keramický kotouč; cel - čelenka; nakr - nákrčník; dykvys- dýka s výstupkem; dukploc - dýka plochá; jehcyp - jehlice cyperská; jehvoc - jehlice v očko; jehter - jehlice terčovitá; jehrou jehlice rourkovitá; vrblih - vrbový list hladký; vrbliz - vrbový list se žebrem; koliCu - měděné lité kopí; draj-jednoduchý drát; drad - dvojitý drát; dradsm - dvojitý drát s jednoduchou smyčkou; dradnsm - dvojitý drát s násobnou smyčkou; sptru - spirálka a spirálovitá trubička; kosou - soudkovitý korál; truple - plechová trubička; pliza - plí̌̌ek zahnutý; nar - náramek; narprek - náramek s přeloženými konci; narspi - spirálovitý náramek; nautPri - náušnice typu Př́́kazy; dena - nátepní destička; sip - šipka; sekB1 - broušená sekera; skrm - sekeromlat; sdg - silicitová dýka; brou - brousek; nasSI - štípaná industrie-nástroj; ust - úštěp; val - valoun; kelk - kančí kel; kosjeh - kostěná jehlice; nasKPI - KPI-nástroj; korkova - kostěnné válcovité korálky; korper - perletové korálky; korfaj - fajánsové korálky; jan - jantar; zebzv - zvířecí žebra; koszv - zvířecí kosti; tur - lebka; rohy tura; dent - dentalium; last - lastura/mušle/ulita.

korálky. O excentricitě esovitých mís byla již řeč, na grafu se k nim přidávají také amfory, typický produkt nitranské kultury (obr. $4 ; 5)$.

\section{Analýza hlavních komponent a analýza hlavních koordinát}

Analýza hlavních komponent (PCA) založená na variančně kovarianční matici poskytla poněkud odlišné výsledky (obr. 6). První dvě komponenty vyčerpaly $15,56 \%$ a 9,61 \% variance, což je více než v prrípadě $C A$, ale shodně s $C A$ ani tato ordinace nedosáhla žádné výrazné extrakce do prvních několika komponent - zdroje variance jsou $\mathrm{v}$ datech evidentně velmi diverzifikovány a redukce není možná.

Analýza hlavních koordinát (PCO; obr. 7) extrahující varianci z matice podobností získaných metodou Raup a Crick (1979) přinesla podobný 


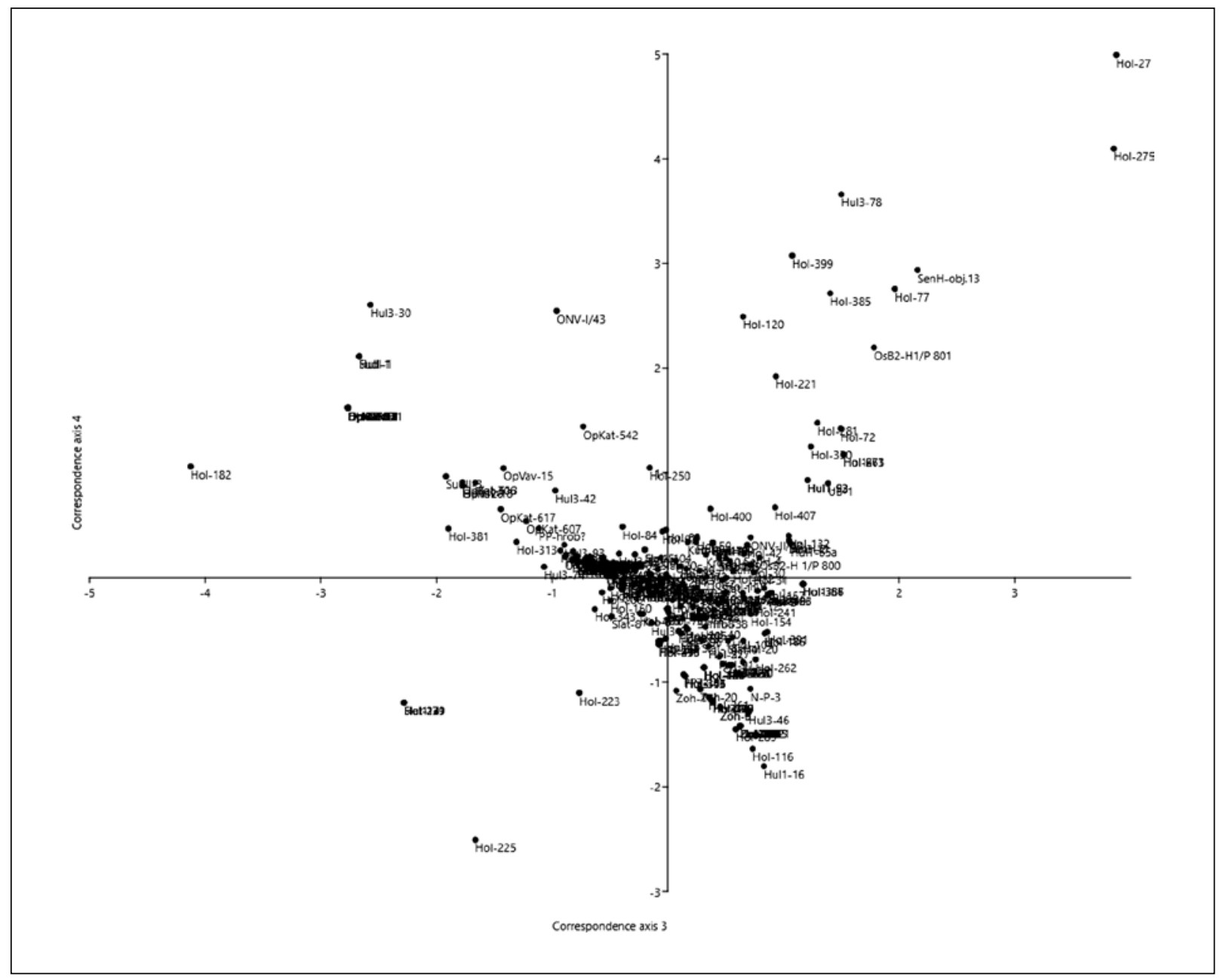

Obr. 5. Bodový graf skóre případů (hrobů) na korespondenčních osách 3 a 4 - výsledku korespondenční analýzy studované incidenční matice.

výsledek jako PCA, první dvě hlavní koordináty vyčerpaly $10,16 \%$ a $6,49 \%$ variance a stejně jako v předchozích metodách další pokles vyčerpané variance byl malý.

\section{Seriace}

Seriace poskytla jednu řadu - relativní pořadí hrobů v závislosti na poloze jejich nálezů na hlavní diagonále (obr. 8) v závislosti na jejich společném výskytu. $V$ průběhu této řady lze vysledovat asi tři skupiny kumulací milodarù. Podle jejich seřazení platí relativní chronologie zhruba zprava doleva. První je vymezena keramikou zdobenou otisky šňưry až vrbovým listem hladkým i se žebrem (zde $\mathrm{v}$ zásadě bez rozlišení) s úzkou návazností na nejširší skupinu artefaktů, kde vrbový list je vystř́idán drátěným šperkem $\mathrm{v}$ posloupnosti: jednoduchý drát - dvojitý drát - dvojitý drát se zpětnou smyčkou a dvojitý drát s násobnou zpětnou smyčkou (až v nejmladší skupině předmětů). Seriace jasně prokázala průběžnost řady milodarů (kostěné válcovité korálky, zvířecí žebra, štípanou industrii a úštěpy) a postuluje správnost pořadí starších fajánsových a mladších perletových korálků. Nesprávná a nejasná je pozice esovitých hrnků zdobených otisky šňůry a kamenných sekeromlatů vlastně na okraji nejmladší skupiny artefaktů, nebở tato kombinace zcela jednoznačně vymezuje nejstarší protonitranskou fázi (viz dále) a náležela by zcela na pravý okraj seriačního spektra. Tak jako v př́padě jiných statistických metod se daří velice dobře vymezit zástupce nejmladších milodarů (díky pohřebišti v Holešově) časově již na úrovni klasické fáze ÚK (náleží sem podstatná část keramiky včetně koflíků, osudí, cyperská, rourkovitá a jehlice s hlavicí svinutou v očko, litý soudkovitý korál a již zmíněná vlasová ozdoba z dvojitého drátu s násobnou zpětnou smyčkou). 


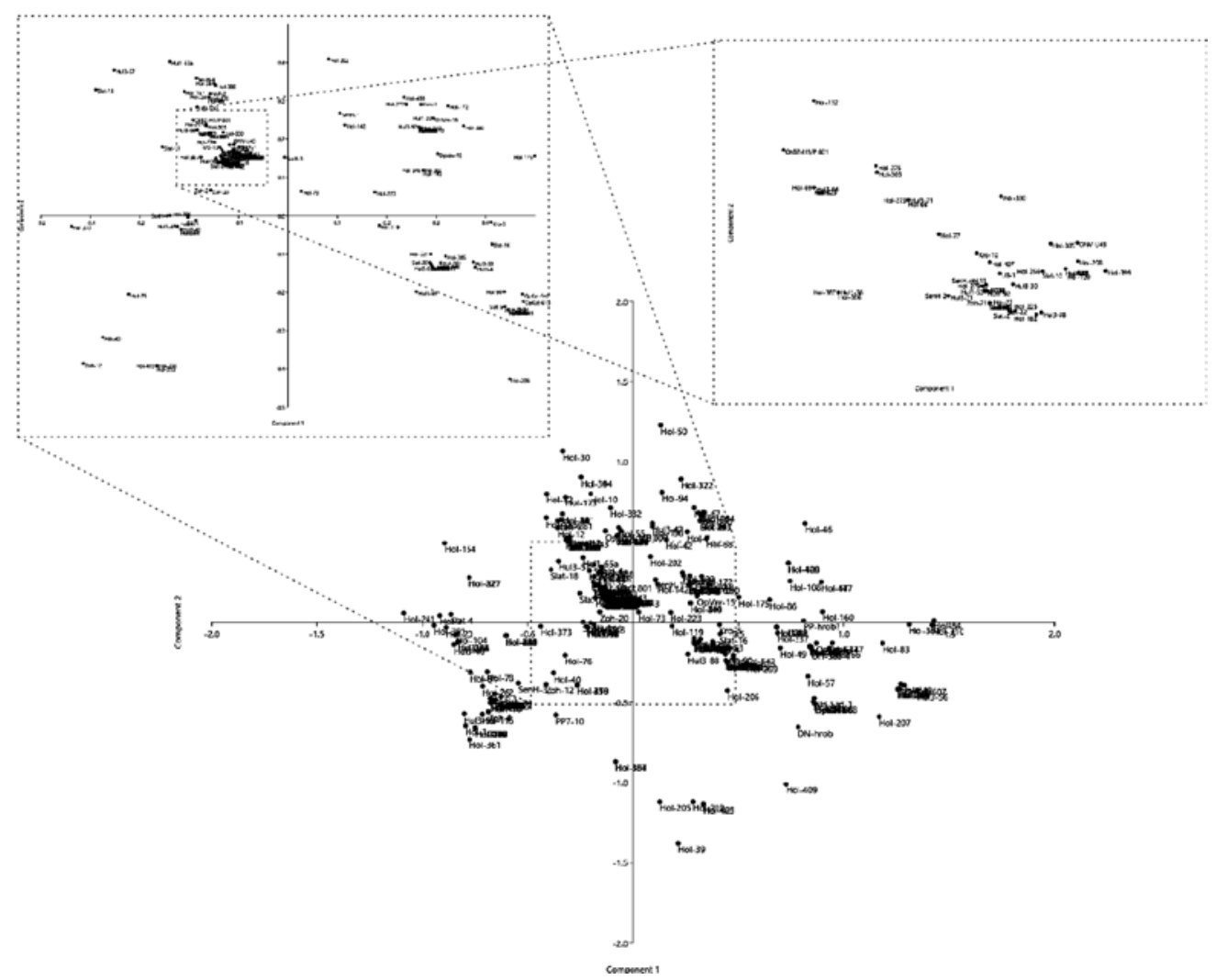

Obr. 6. Bodový graf skóre PC1 a PC2 analýzy hlavních komponent.

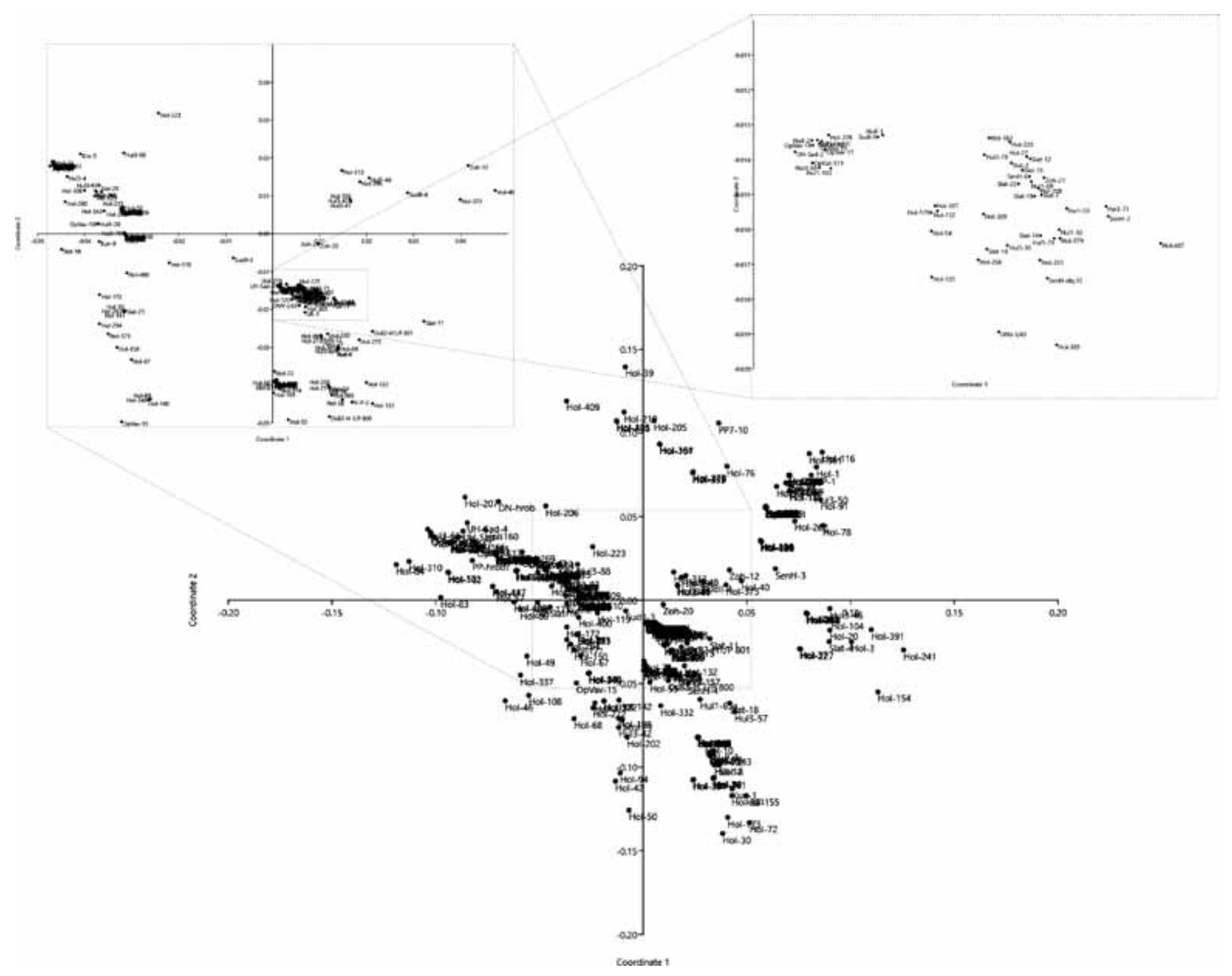

Obr. 7. Bodový graf skóre PCo1 a PCo2 analýzy hlavních koordinát. 


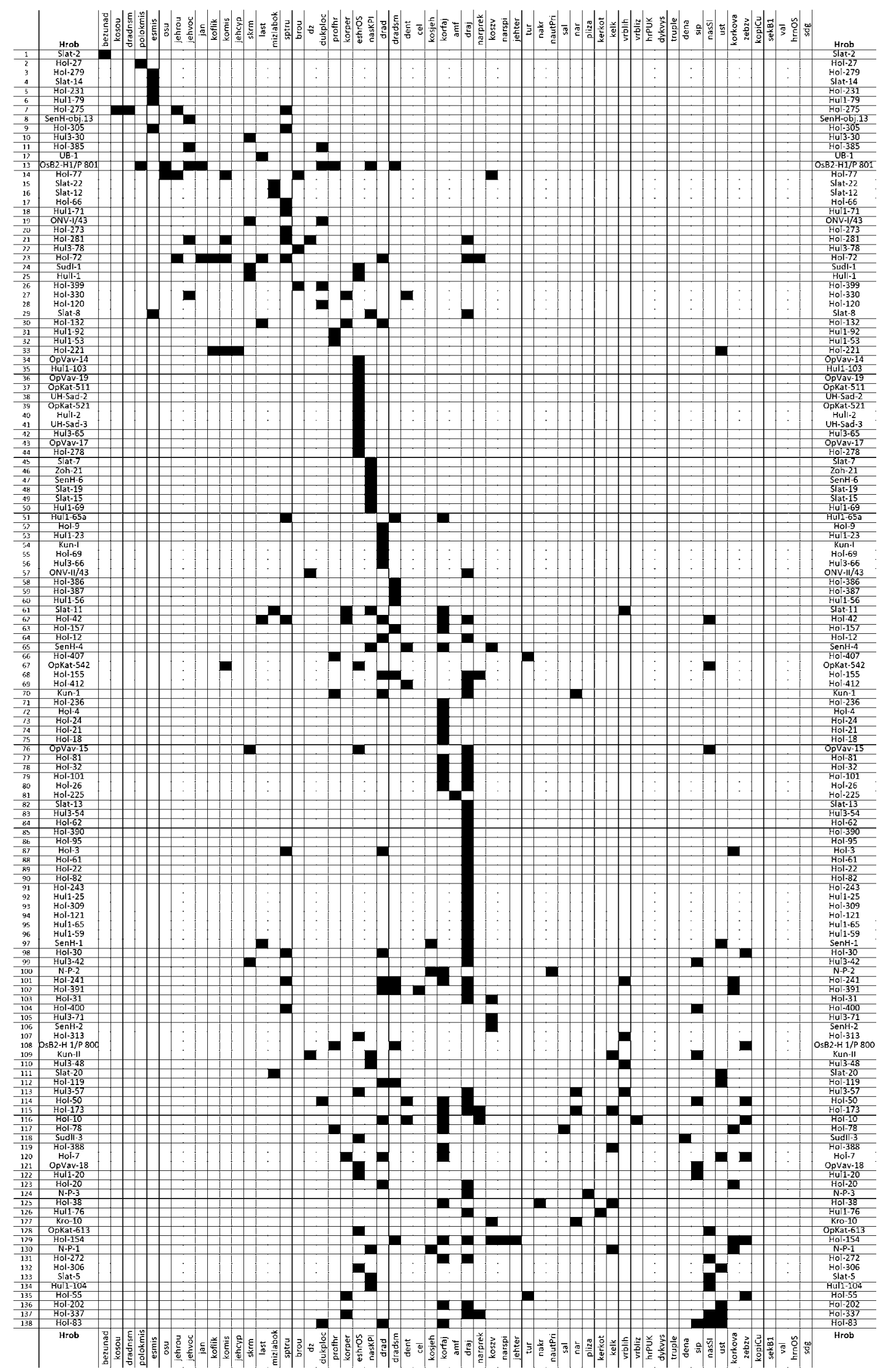

Obr. 8. Výsledky seriace incidenční matice metodou Brower a Kile (1988) s neomezeným nastavením (t.j. změnou pořadí jak proměnných, tak př́ípadů). 


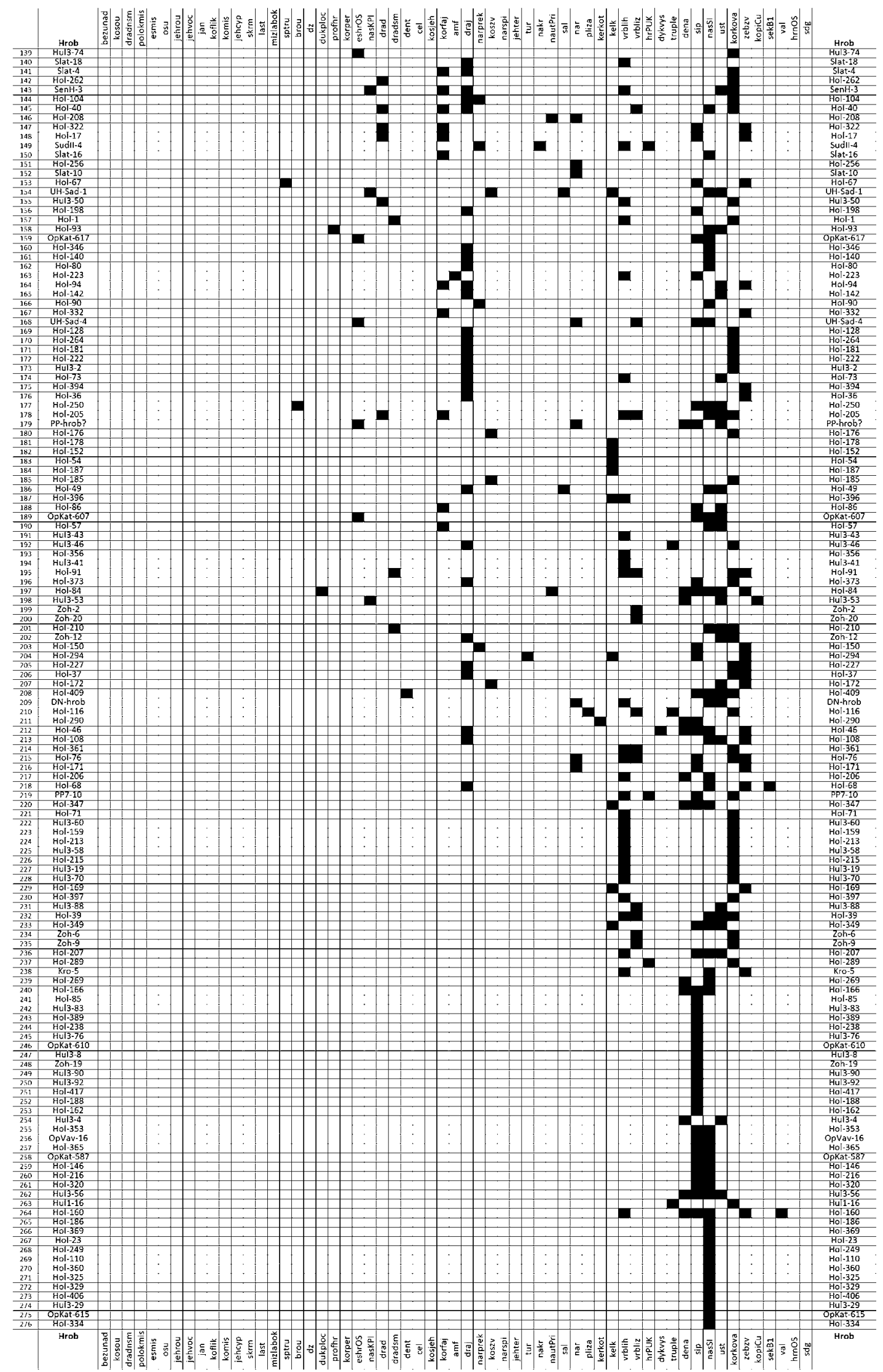

Obr. 8. Pokračování. 


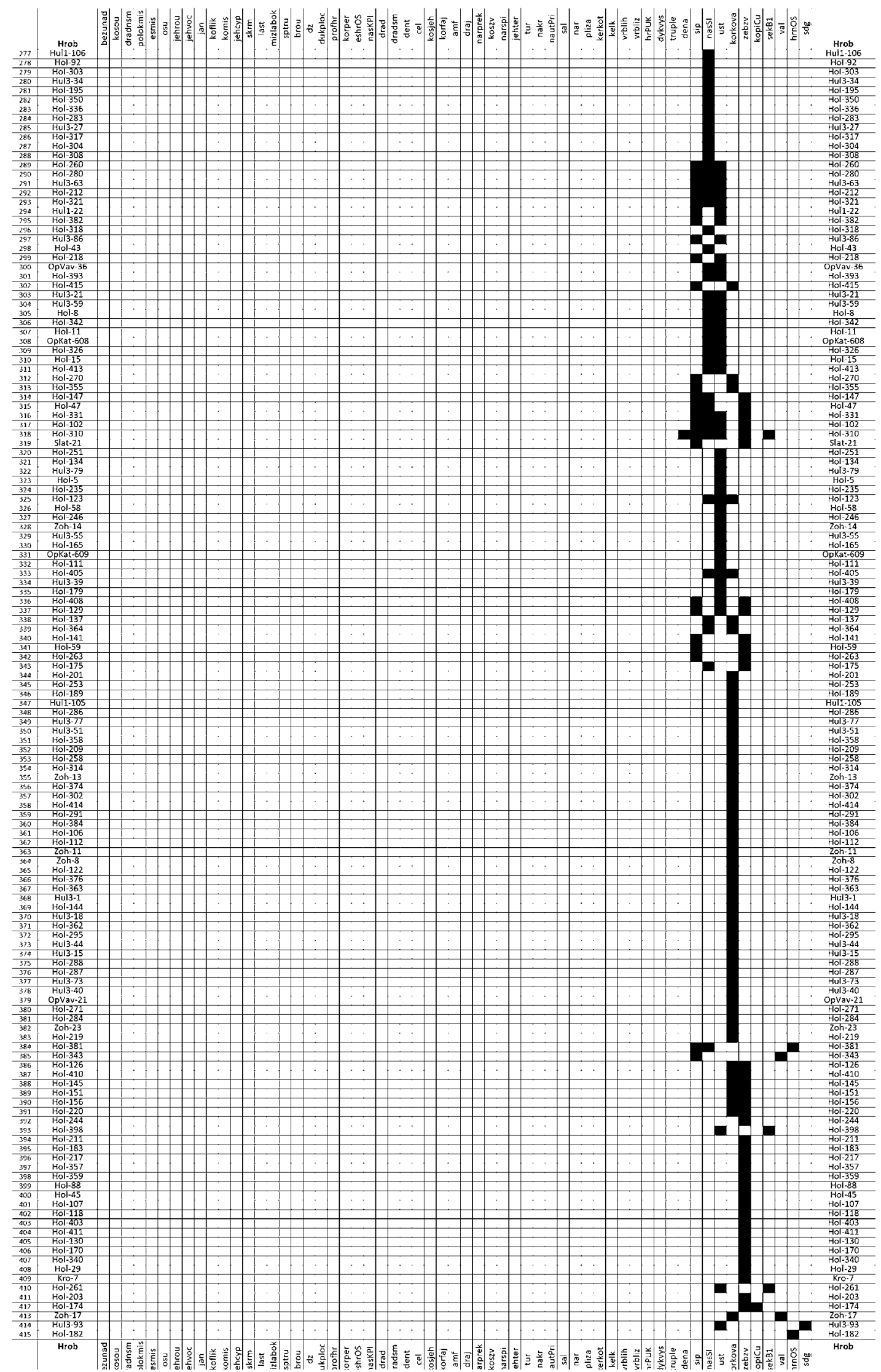

Obr. 8. Pokračování. 


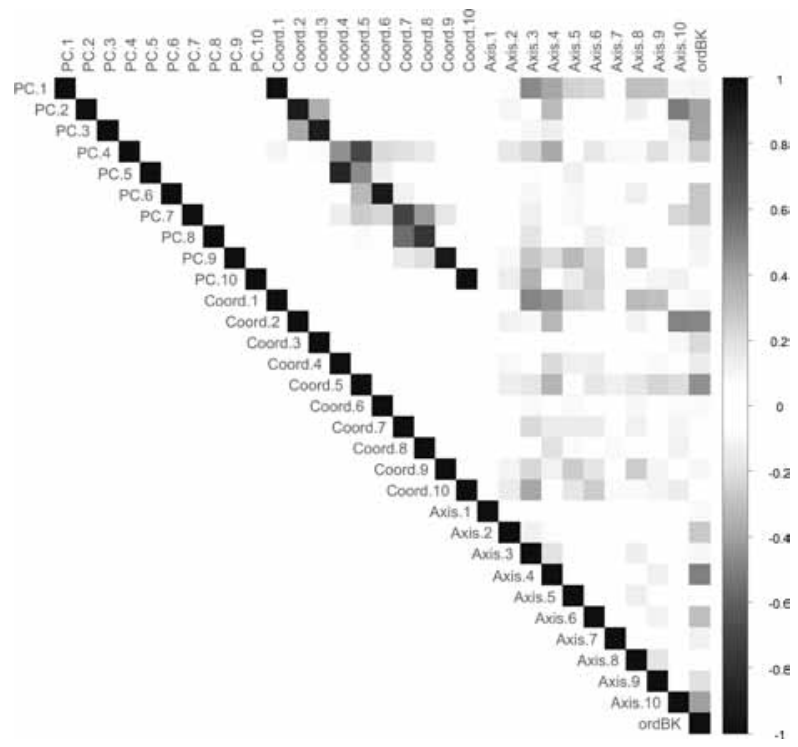

Obr. 9. Korelační matice, sumarizující barevně (smysl korelace) a intenzitou (míra korelace) souvislosti mezi získanými skóre (či pořadím) z ordinačních metod PCA (PC.1-PC.10), PCO (Coord1-Coord10), korespondenční analýzy (Axis 1-Axis 10) a seriace (ordBK) na celém souboru analyzovaných dat.

Vyčlenění bezuché esovité nádobky z H 2 ve Slatinkách, náležící $\mathrm{k}$ běžné nitranské produkci na samotný levý okraj pořadí, může být způsobeno jejím osamocením (čili bez vazby na jakýkoliv jiný milodar). I přes jisté problémy lze konstatovat, že také seriace $\mathrm{v}$ zásadě potvrdila chronologické tendence kombinace hrobových př́idavků a není $\mathrm{v}$ rozporu s našimi závěry.

\section{Korelace ordinace s absolutními daty}

Korelační matice (obr. 9) ukazuje na plném souboru $(\mathrm{n}=415)$ korelace mezi ordinačními komponentami všech použitých metod. Jednotlivé komponenty PCA spolu (z definice) vzájemně nekorelují, ale silně korelují s hlavními koordinátami PCO - prakticky až na mírné posuny (přehození některých dvojic) a změnu znaménka vyčerpala PCO z dat jiným algoritmem a zcela jinou metrikou velmi podobné, někdy až prakticky totožné komponenty. Korespondenční analýza pořádá varianci v datech zcela odlišným způsobem a výsledné osy $s$ předchozími dvěma korelovaly jen slabě; nejsilněji osa $3 \mathrm{~s}$ PC1 a osa $10 \mathrm{~s}$ PC2. Seriace metodou Brower/Kile (1988) poskytuje ještě jinak odlišnou osu, která asi nejsilněji korelovala s osou 4 korespondenční analýzy.

Pokud jsme omezili př́ipady korelační matice pouze na hroby s dostupnými absolutními daty

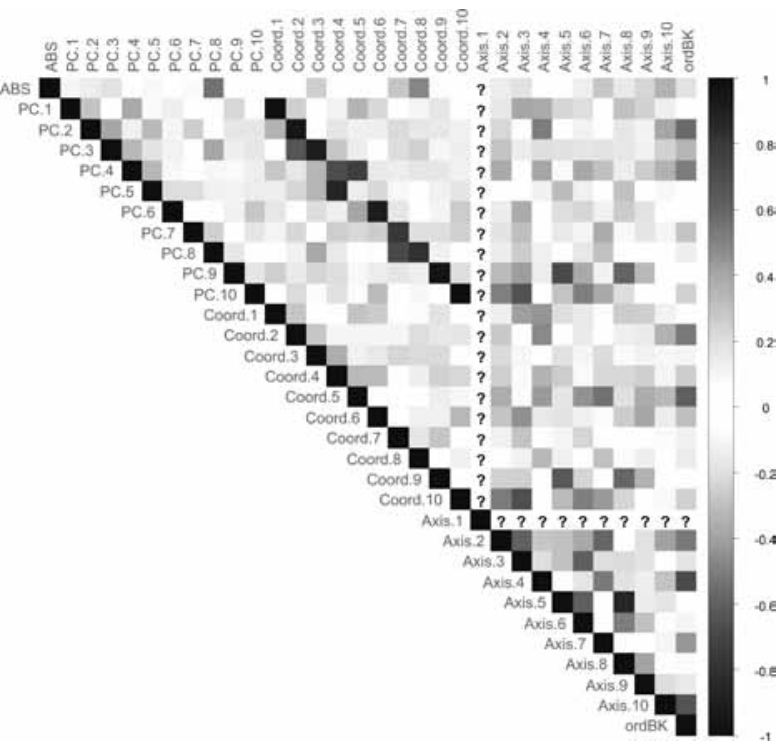

Obr. 10. Korelační matice (korelogram), sumarizující barevně (smysl korelace) a intenzitou (míra korelace) souvislosti mezi získanými skóre (či pořadím) z ordinačních metod PCA (PC.1-PC.10), PCO (Coord1-Coord10), korespondenční analýzy (Axis 1-Axis 10) a seriace (ordBK) s absolutními radiouhlíkovými daty $\left(\mathrm{C}^{14}\right) \mathrm{u}$ výběru případů (graves) s dostupnými absolutními daty.

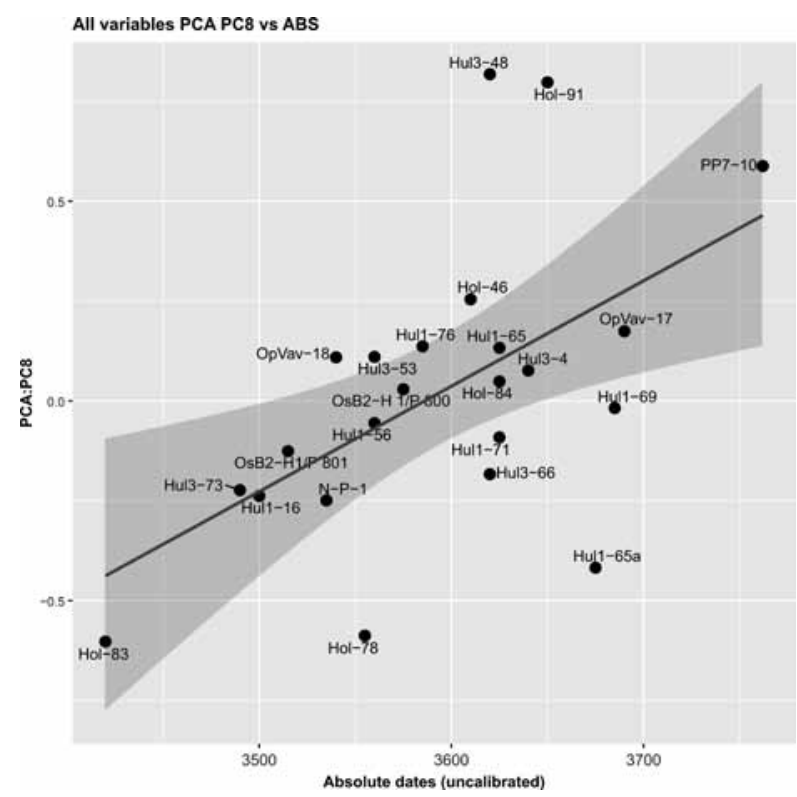

Obr. 11. Bodový graf závislosti skóre PC8 z PCA (na ose y) na hodnotě nekalibrovaných absolutních dat u výběru hrobů $\mathrm{s}$ dostupnými absolutními daty.

$(n=23)$, vztah PCA komponent a PCO koordinát se př́liš nezměnil (obr. 10). $S$ absolutními daty výrazněji korelují pouze dvě komponenty, a to PC8 z PCA $(r=0,55)$ a Coord 8 z PCO $(r=-0,48)$. Jedná se tedy o středně silné korelace, naznačující, že rela- 


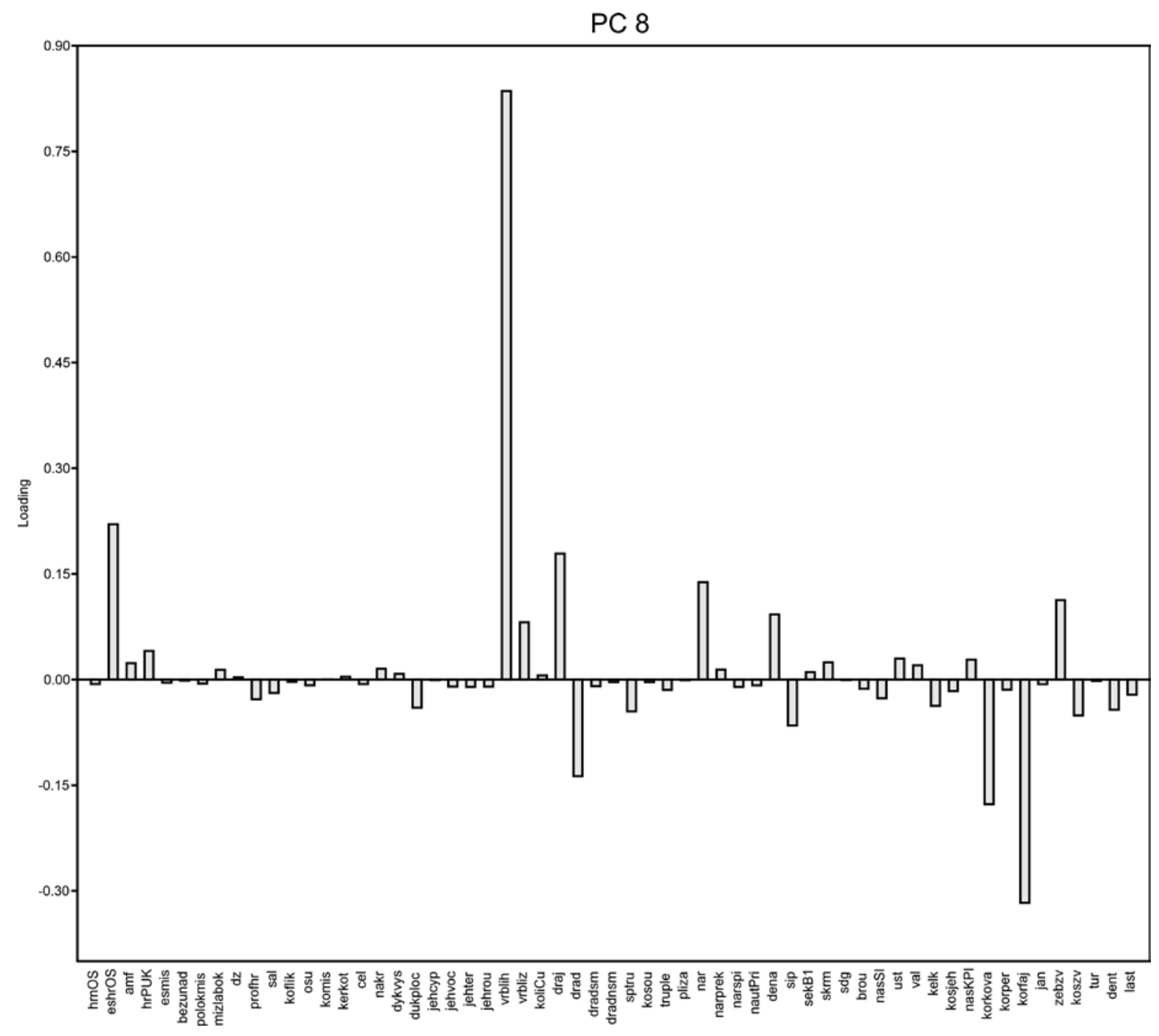

Obr. 12. Sloupcový graf zátěží proměnných na PC8 z PCA; pro srovnání s obr. 11 (osa y).

tivně velký podíl variance $\mathrm{v}$ těchto komponentách souvisí s variancí v absolutních datech (obr. 11). Vzhledem k tomu, v PC8 korelovala silněji než Coord8 a navíc v plných datech obě komponenty byly prakticky totožné, zaměřili jsme se $\mathrm{v}$ interpretaci na PC8.

Kladné hodnoty komponenty PC8 (vysoká absolutní data, tzn. relativně starší hroby) jsou saturovány zejména zátěžemi původních proměnných: zvířecí žebra (zebzv), nátepní destičky (dena), náramky (nar), jednoduchý drát (draj), esovitě profilované hrnky s otisky šňůry (eshrOS), vrbový list hladký (vrblih), vrbový list se žebrem (vrbliz), zatímco její záporné hodnoty (nízká absolutní data, tzn. relativně mladší hroby) jsou saturovány především zátěžemi pưvodních proměnných: fajánsové korálky (korfaj), kostěné válcovité korálky (korkova) a dvojitý drát (drad; obr. 12), což rámcově odpovídá našim jiným zjištěním, přesto, že část

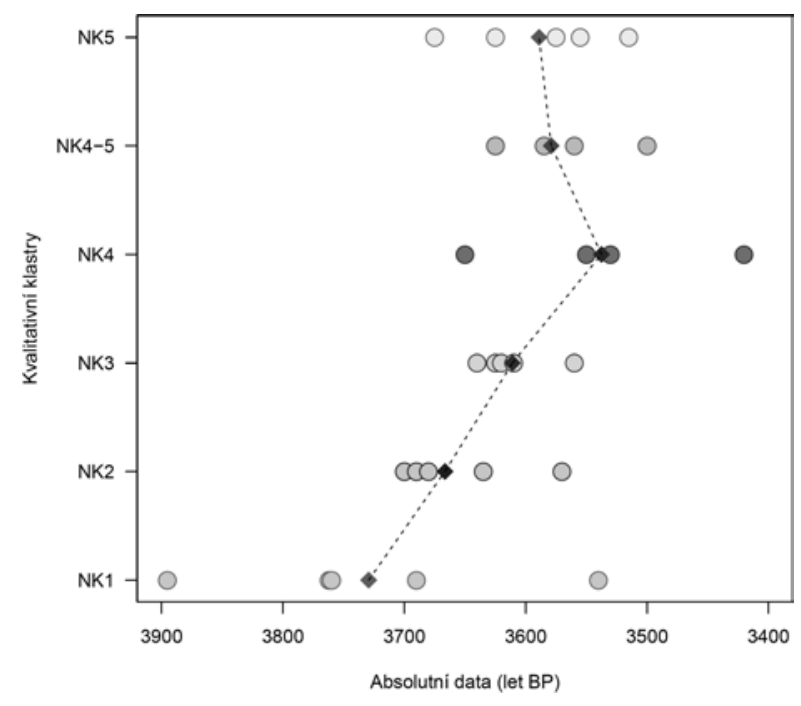

Obr. 13. Kvalitativní klastry absolutních dat z hrobů NK s vyznačením mediánu. 


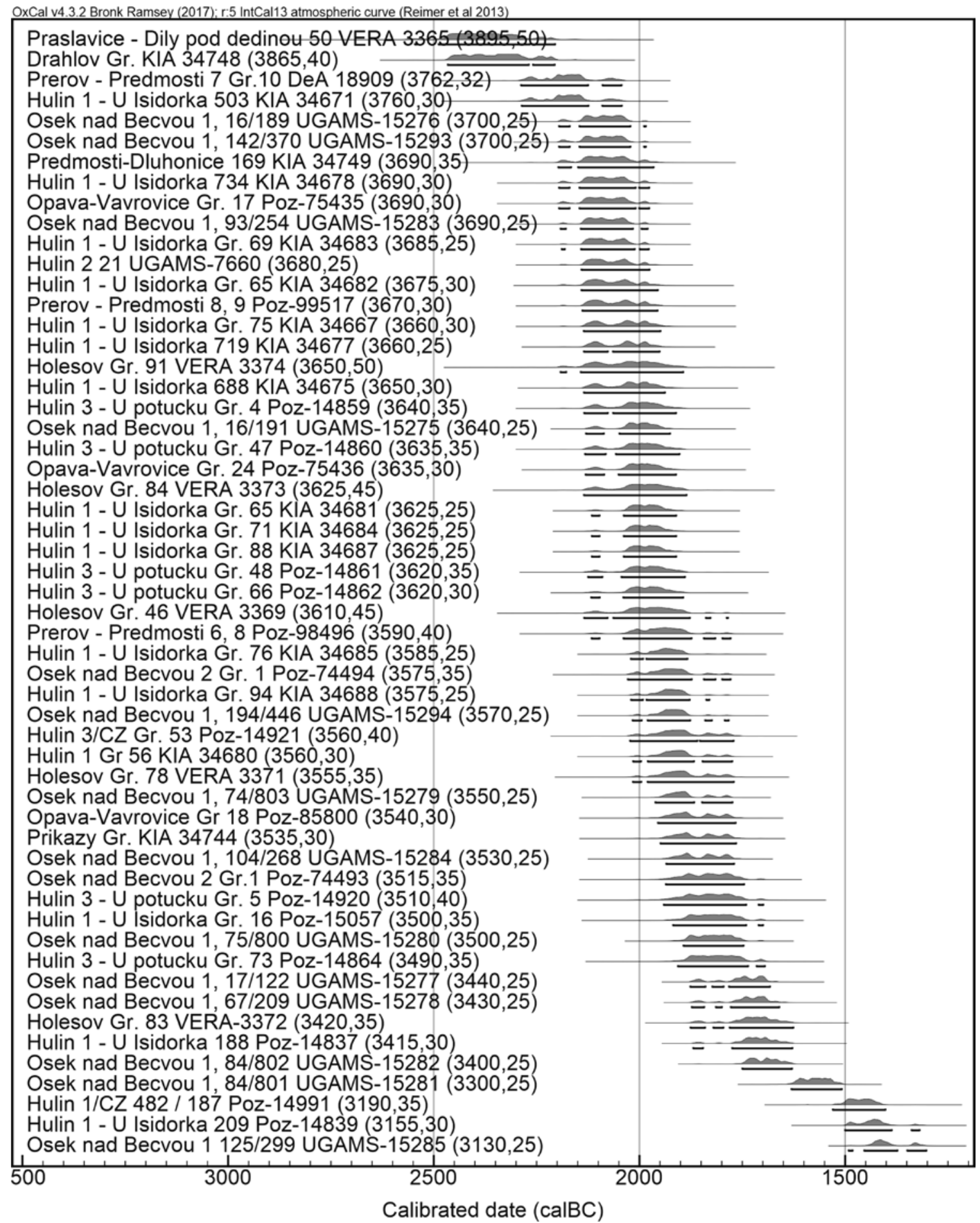

Obr. 14. Nitranská kultura na Moravě a ve Slezsku. Přehled kalibrovaných radiouhlíkových dat. Program OxCal v.4.3.2.

proměnných je průběžná a vyskytuje se v hrobech po delší dobu.

Je třeba ovšem zdůraznit, že PC8 v provedené analýze je až osmá hlavní komponenta $\mathrm{z}$ hlediska množství vyčerpané variance $(4,6 \%)$, předchozí a podstatnější komponenty s absolutními daty koreluji mnohem slaběji nebo vůbec, a že tato část variance tedy rozhodně není tím hlavním, $\mathrm{v}$ čem se mezi sebou analyzované případy liší. Vysvětlení si tedy žádalo také předešlých sedm komponent, na to však $\mathrm{v}$ této studii není prostor.

Srovnání externích, kvalitativně zkušeností definovanými časovými skupinami v rámci nitranské kultury s daty absolutní chronologie ukazuje, že 


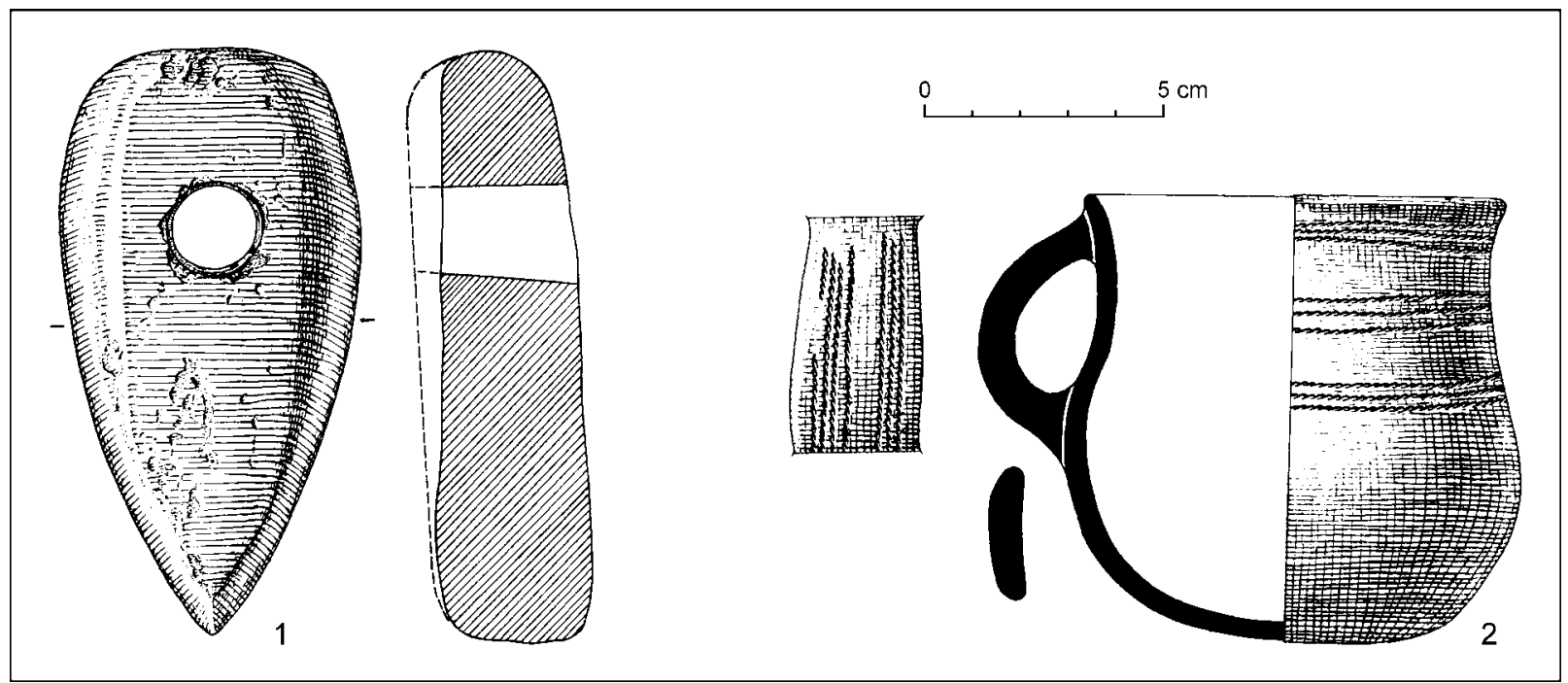

Obr. 15. Hulín I. Hrobový inventář protonitranské fáze (NK1). Podle Peška/Šebela 1992, upraveno.

průměrné hodnoty nej- a staršího období NK až po klasickou fázi kultury (NK1-4) mají jasně postupnou tendenci s překryvem $\mathrm{v}$ okrajových částech sekvence. Problém je s vyvrcholením kultury (NK4-5 a NK5), které by mělo být podle absolutních dat dokonce $\mathrm{v}$ průměru o něco starší než klasická NK (obr. 13). Dostupná série dat z hrobových kontextů není velká $(n=23)$ a připustíme-li možnost chybnosti nebo nepřesnosti jisté části dat, můžeme vidět př́ćciny ne zcela uspokojivého výsledku korelace. Podobný problém jsme nuceni řešit také u celkového přehledu absolutních dat EPKK (obr. 14), kde jak počáteční, tak především koncová data nebudou asi ani do budoucna akceptovatelná.

\section{NOVÁ TERMINOLOGIE A VNITŘNÍ PERIODIZACE}

Jak bylo již naznačeno výše, panuje v odborné literatuře kolem epišňůrové etapy vývoje starší doby bronzové značná terminologická nejednotnost a nejasnosti s tím, že na Moravě v jižní části Horního Slezska navíc postrádáme jasnou interní periodizaci tohoto úseku. Důležitým bodem je akceptace neexistence chronologicky jednotné formace Chłopice-Veselé, která se rozpadá do dvou fází, byṫ byla již předtím vnímána jako počáteční období nitranské kultury (Peška 1989) a následné nové zhodnocení dosavadního členění celé periody Reineckeho stupně BA1. $K$ tomu je nutno vyjasnit nebo poupravit dosud používanou terminologii. Například v př́ípadě nejstarších projevů únětické kultury na Moravě (i jinde) je nesprávně zaměňován coby synonymum pojem protoúnětická a časně únětická kultura, přičemž oba pojmy mají i svou jasnou časovou diferenci (proto jako něco velmi těsně předcházejícího, časný - rané stadium entity). Přestože podobně jako $\mathrm{v}$ př́padě vztahu dřívější Chłopice-Veselé - Nitra se jedná u protoúnětické o nejstarší etapu únětické kultury, z důvodu hluboké tradice a hlavně možnosti vnitřního členění (cf. Peška 2009, 253 ad.) zachováváme tradiční označení protoúnětická kultura. Použít obdobný termín (nitransko-únětická fáze únětické kultury) pro označení závěru nitranské kultury, resp. nástupu únětické kultury v Karpatské kotlině se zcela odlišnou (materiálově i časově) náplní, nepovažujeme za vhodné, podobně jako jednu periodu se stejnou absolutní datací nahlížet jednou ze strany kultury předcházející a podruhé ze strany kultury následující, když se zjevně jedná o tutéž fázi s totožným inventářem. Zavádějícím synonymem je de facto i termín nitransko-únětická fáze (Bátora 2000, 514; 2018, 80, 89 n.; Bátora/Vladár 2015, 24 n.), navozující dojem, např́íklad ve srovnání věcně správné úněticko-mad’arovské fáze, genetické vazby obou jednotek, která zde zjevně neplatí, nebot do Karpatské kotliny se únětická kultura dostává až plně zformovaná na počátku své klasické fáze.

Na základě dosavadního bádání a s ohledem na vývoj v okolních regionech předkládáme novou vnitřní periodizaci epišňůrového vývoje (BA1) na Moravě a na moravskoslezském pomezí se stručnou charakteristikou náplně. Přitom je potřeba znovu zdůraznit, že jednotlivá chronologická období (stupeň, fáze, horizont) nemají fixní hranice a jejich počáteční a konečná stadia se (nejspíše i absolutně chronologicky) prolínají. 


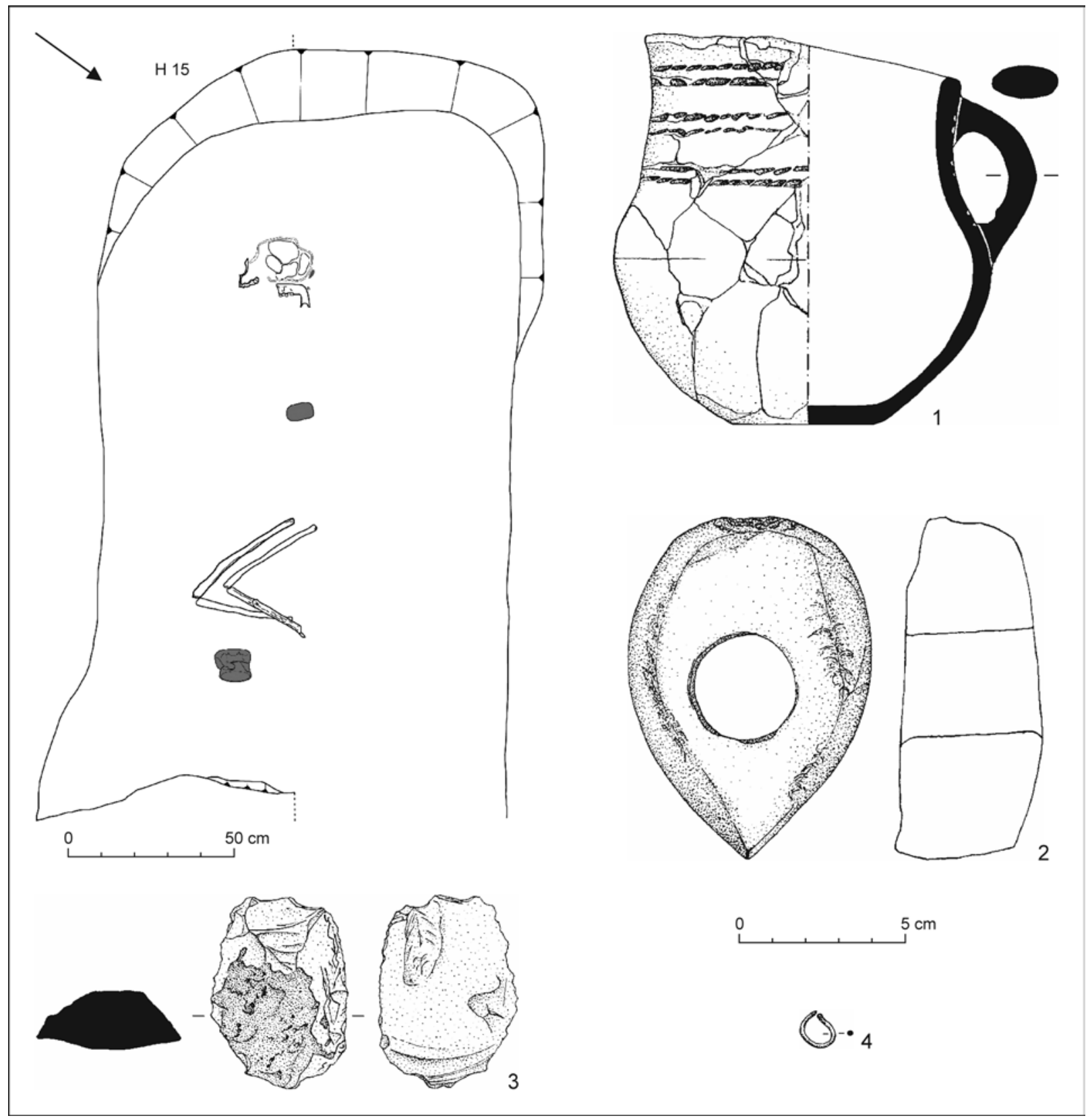

Obr. 16. Opava-Vávrovice-Krásná pole. Inventář H 15 protonitranské fáze (NK1).

\section{Nová periodizace EPKK, resp. nitranské/mierzanovické kultury}

Pro přehlednost uvádíme nejdříve návrh nové periodizace a následovně charakteristiku jednotlivých fází na základě inventáře hrobových celků (z důvodu nedostatku a nerovnoměrnosti rozložení absolutních dat - minimální zastoupení nejstarších fází - zatím upouštíme od stanovení jejich absolutně chronologických hodnot).

Za jediného zástupce EPKK na Moravě a ve Slezsku považujeme nitranskou/mierzanovickou kulturu, kterou navrhujeme členit takto:
- protonitranská fáze (EPKK I, Přáslavice?, Hulín I, Uherský Ostroh, Opava-Vávrovice H 15, 17, 18; Přerov-Předmostí $7 \mathrm{H} \mathrm{10)}$ časově na úrovni Chłopice (obr. 15; 16);

- časně nitranská fáze (EPKK IIa, IIb, Přáslavice, Sudoměřice I, Sudoměřice II, Opava-Vávrovice H 14, Opava-Kateřinky, nejstarší hroby v Holešově) časově na úrovni Veselé (obr. 17-19);

- starší nitranská fáze (EPKK III, 2. a 3. horizont v Holešově) konec PÚK ? a 2. fáze ÚK? (obr. 20-22);

- klasická nitranská fáze (4. horizont v Holešově, Př́́kazy, Hulín 1, Hulín 3) 2. fáze ÚK (obr. 23-25); 


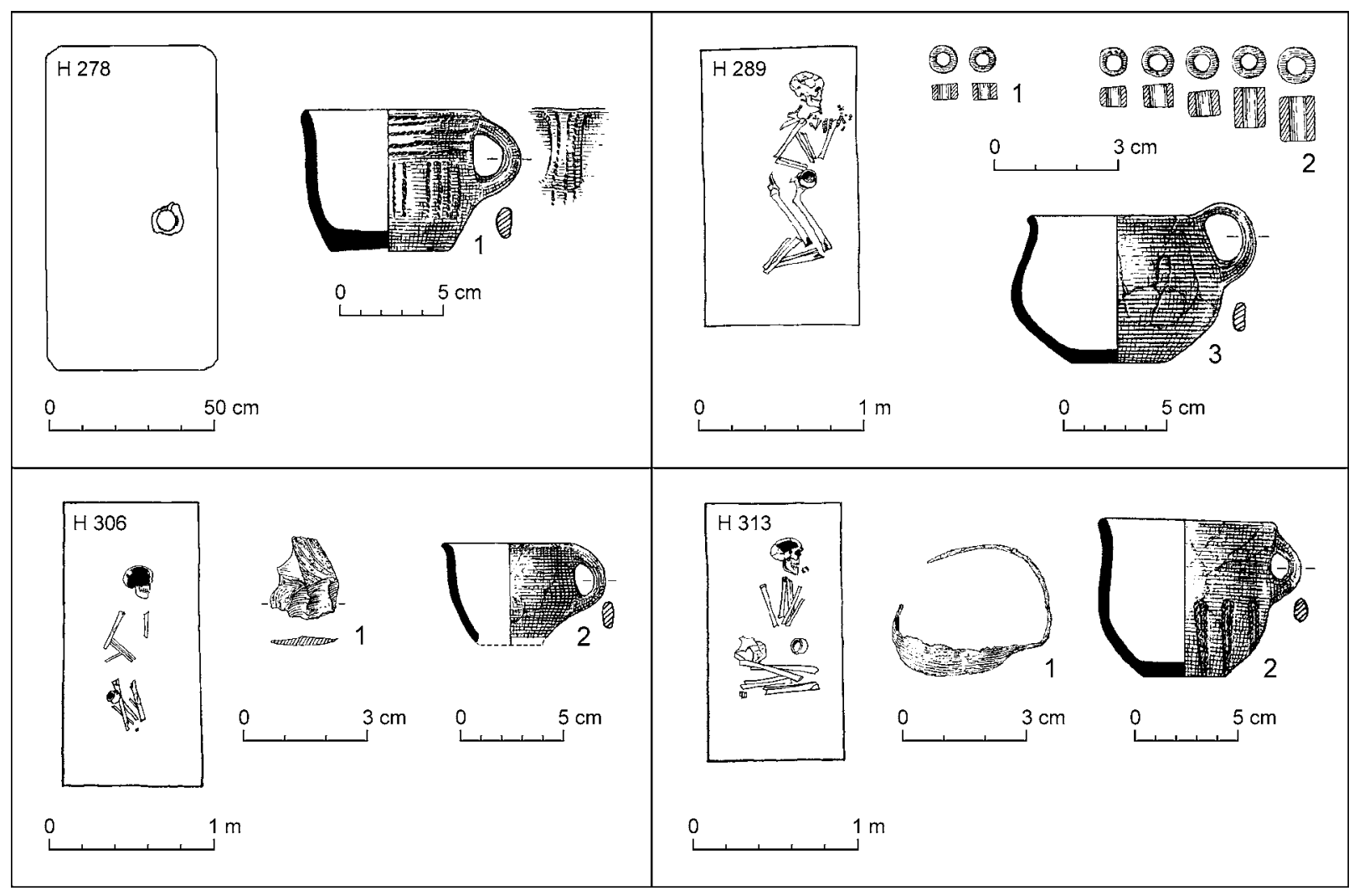

Obr. 17. Holešov-Zdražilovsko. Výběr nejstarších hrobů na pohřebišti - časně nitranská fáze (NK2). Podle Ondráček/ Šebela 1985, upraveno.

- poklasická nitranská fáze (5. horizont v Holešově, Osek nad Bečvou 2) 3. fáze předklasická ÚK (obr. 26-28).

\section{Charakteristika jednotlivých fází}

Protonitranská NK1 - keramika s převahou esovitých hrnků zdobená otisky šňůry ve formě horizontálních násobných linií (nejčastěji na hrdle a plecích), kamenné sekeromlaty připomínající šňưrové, šipky, nátepní destičky, kostěné válcovité korálky jako součást náhrdelníků, industrie ve tvaru vrbového listu (jen hladký?).

Časně nitranská NK2 - keramika (hrnky, polokulovité šálky) nezdobená i zdobená otisky šňưry (kombinace horizontálních a vertikálních pravidelně rozložených linií, smyčky, zakončení důlky, výzdoba celého těla, včetně ucha, plastické aplikace), protoúnětická keramika, šipky, nátepní destičky, štípaná industrie, kostěné válcovité korálky, vrbový list hladký i se žebrem, drátěný nákrčník, náramky. Často není možné obě fáze od sebe oddělit, což do jisté míry platí i pro následnou starší nitranskou kulturu. Jistý rozdíl mezi starším a mladším horizontem sice vnímáme (cf. EPKK IIa a IIb), avšak pro zjednodušení zahrnujeme vše pod tuto fázi.
Starší nitranská NK3 - keramika zdobená otisky šňůry, avšak typologicky svébytná, vyspělá protoúnětická a starší únětická keramika, nátepní destičky, šipky, kančí kly, štípaná industrie, kostěné válcovité korálky, fajánsové korálky, vrbový list hladká a se žebrem, drátěné ozdoby z jednoduchého i dvojitého drátu, drátěný nákrčník, lunicovitá náušnice typu Př́kazy, dýka s výstupkem typu Holešov. Přestože část nálezů může stát přesně na pomezí časné a starší fáze, zařazujeme je do této fáze, přičemž nevylučujeme, že některé celky mohou být i starší. Zde se asi nejvíce projevují neostré hranice mezi jednotlivými úseky.

Klasická nitranská NK4 - typická nezdobená nitranská keramika (esovité mísy, dvouuché nádobky), staroúnětická keramika, kostěné a fajánsové korál$\mathrm{ky}$, trubičky dentalia, kostěné a parohové nástroje (kladivo, motyka, sekeromlat), zvířecí žebra, vrchol štípané industrie, šipky, vrbový list hladký i se žebrem, jednoduchý drát, dvojitý drát i se zpětnou kličkou (Noppenring), náramky s přeloženými konci, plechové trubičky, plechové ozdoby zahnuté, spirálovité trubičky, ploché triangulární dýky.

Poklasická nitranská NK5 - keramika vysloveně únětického rázu, předklasické formy (šálky, profilované až ostřeji profilované hrnky), kostěné, fajánsové a perletové korálky, spirálovité trubičky, 


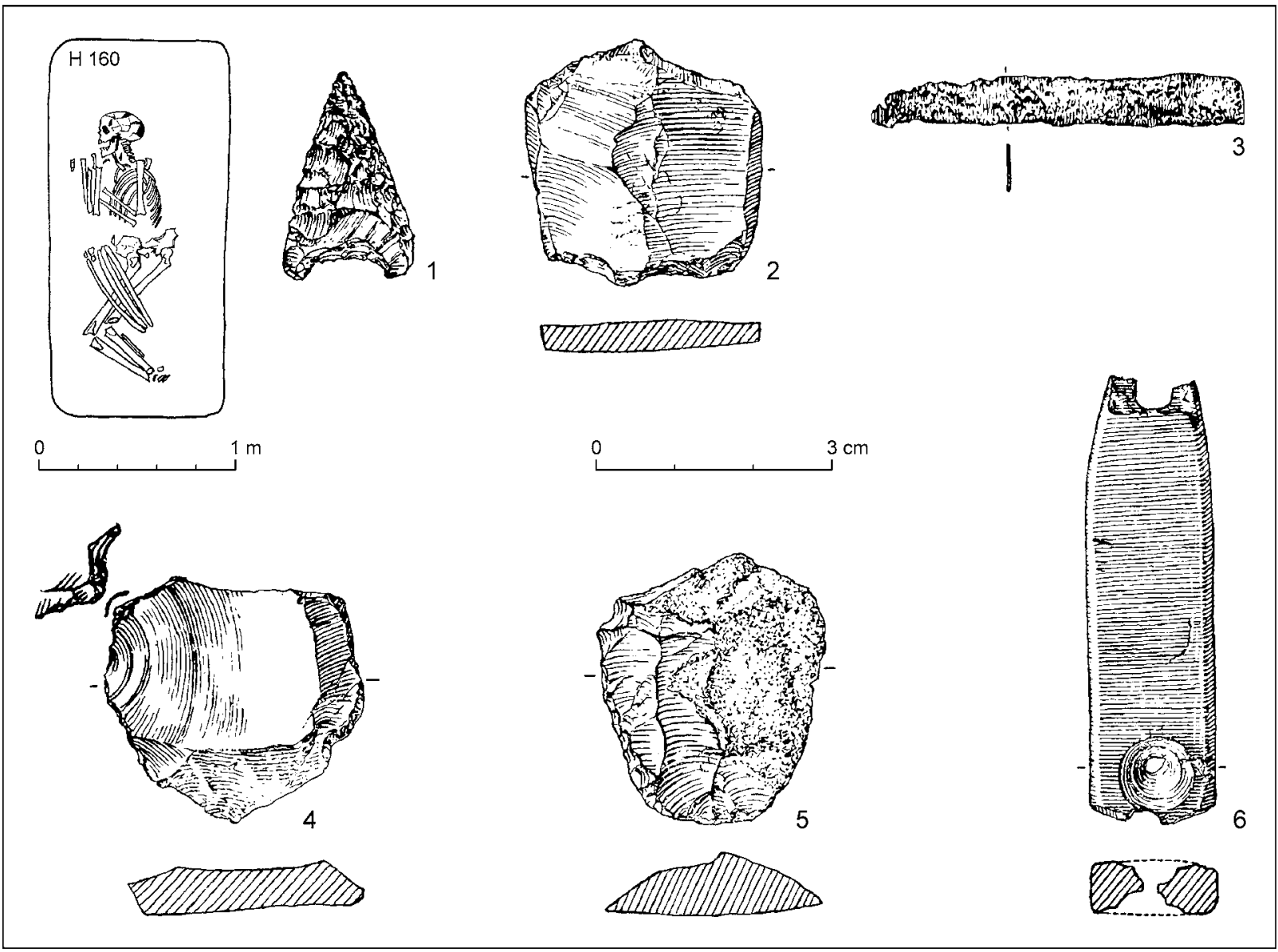

Obr. 18. Holešov-Zdražilovsko. Inventář H 160 - časná až starší nitranská fáze (NK2-3). Podle Ondráček/Šebela 1985, upraveno.

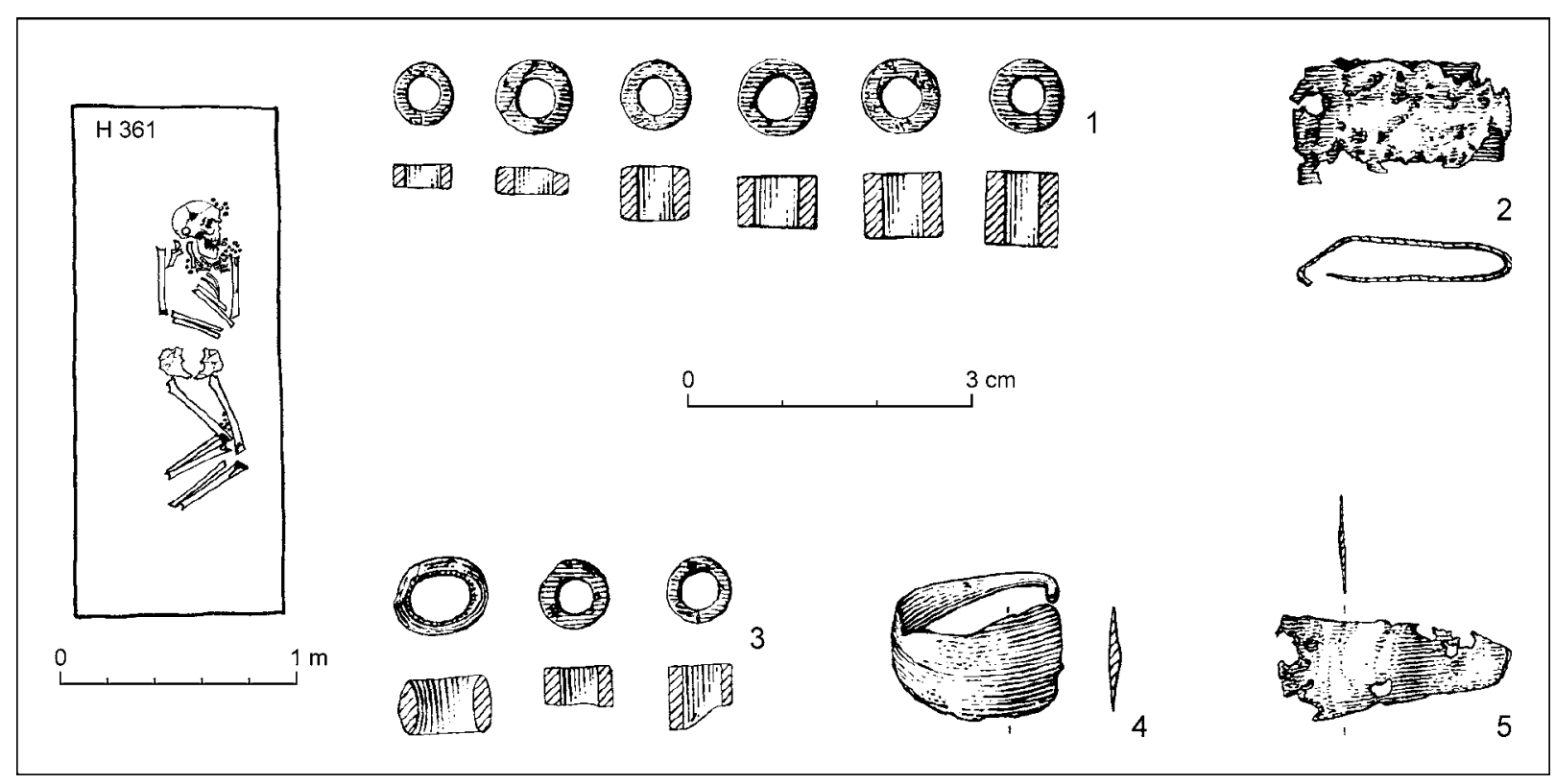

Obr. 19. Holešov. Zdražilovsko. Inventář H 361 - časná až starší nitranská fáze (NK2-3). Podle Ondráček/Šebela 1985, upraveno. 


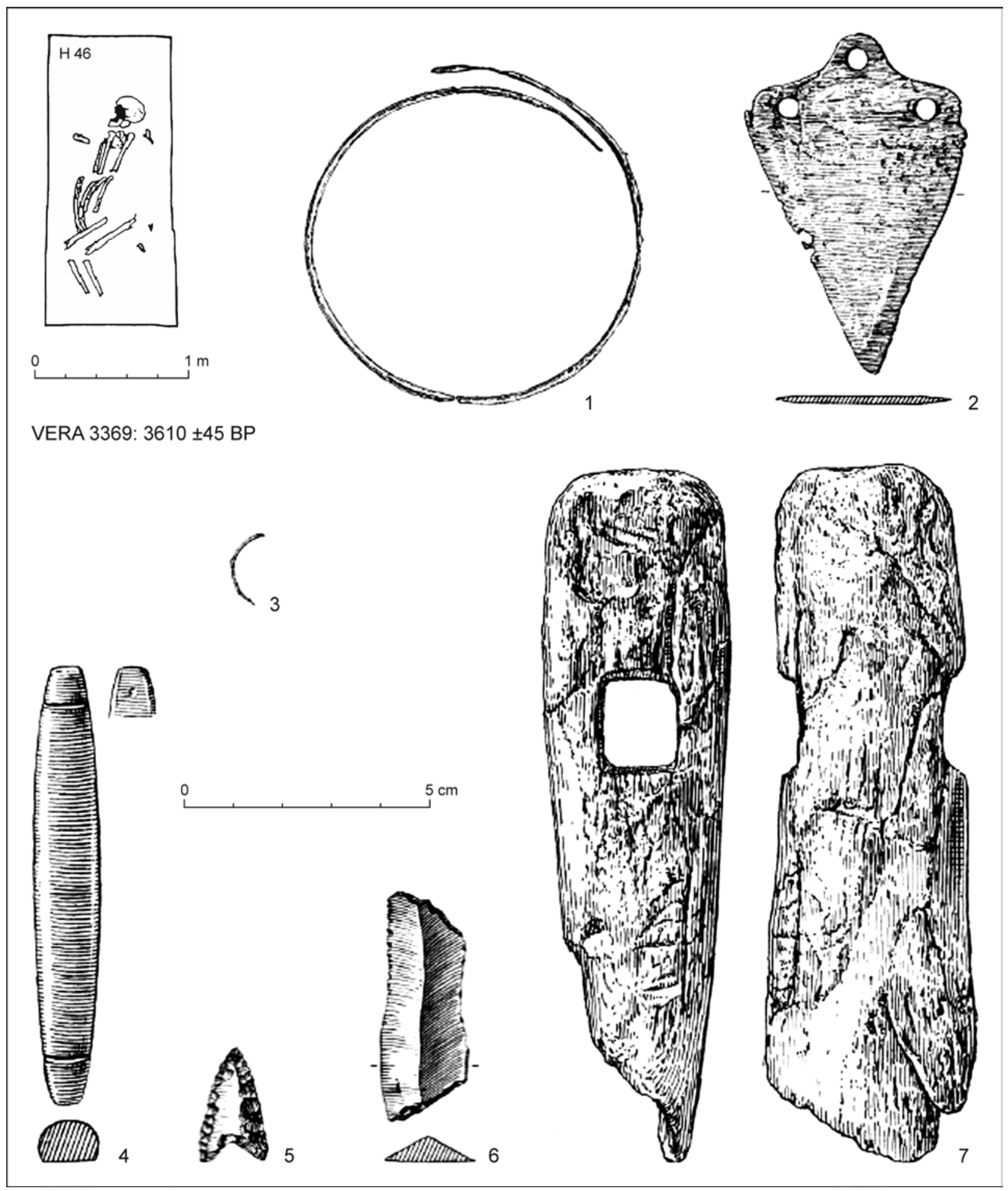

Obr. 20. Holešov-Zdražilovsko. Inventář H 46 - starší nitranská fáze (NK3). Podle Ondráček/Šebela 1985, upraveno.

dentalium, zvířecí žebra, už jen drátěná industrie, často se zpětnou kličkou, náramky s přesahujícími se konci, spirálovité náramky plechová čelenka, terčovitá jehlice, jehlice $\mathrm{s}$ hlavicí svinutou $\mathrm{v}$ očko ploché dýky mladší (zdobené).

Uvědomujeme si patrně největší úskalí komparativních metod, kde nejméně "čitelné" (stati- sticky) je vyčlenění obou mladších fází (klasická a poklasická NK4 a 5), které jsou však po typochronologické linii zcela zřejmé. V tomto př́padě jsme nuceni upřednostnit typologickou stránku věci. Na poklasickou fázi NK již mimo její vlastní rámec plynule navazuje klasická fáze únětické kultury (6. horizont pohřbívání v Holešově). 


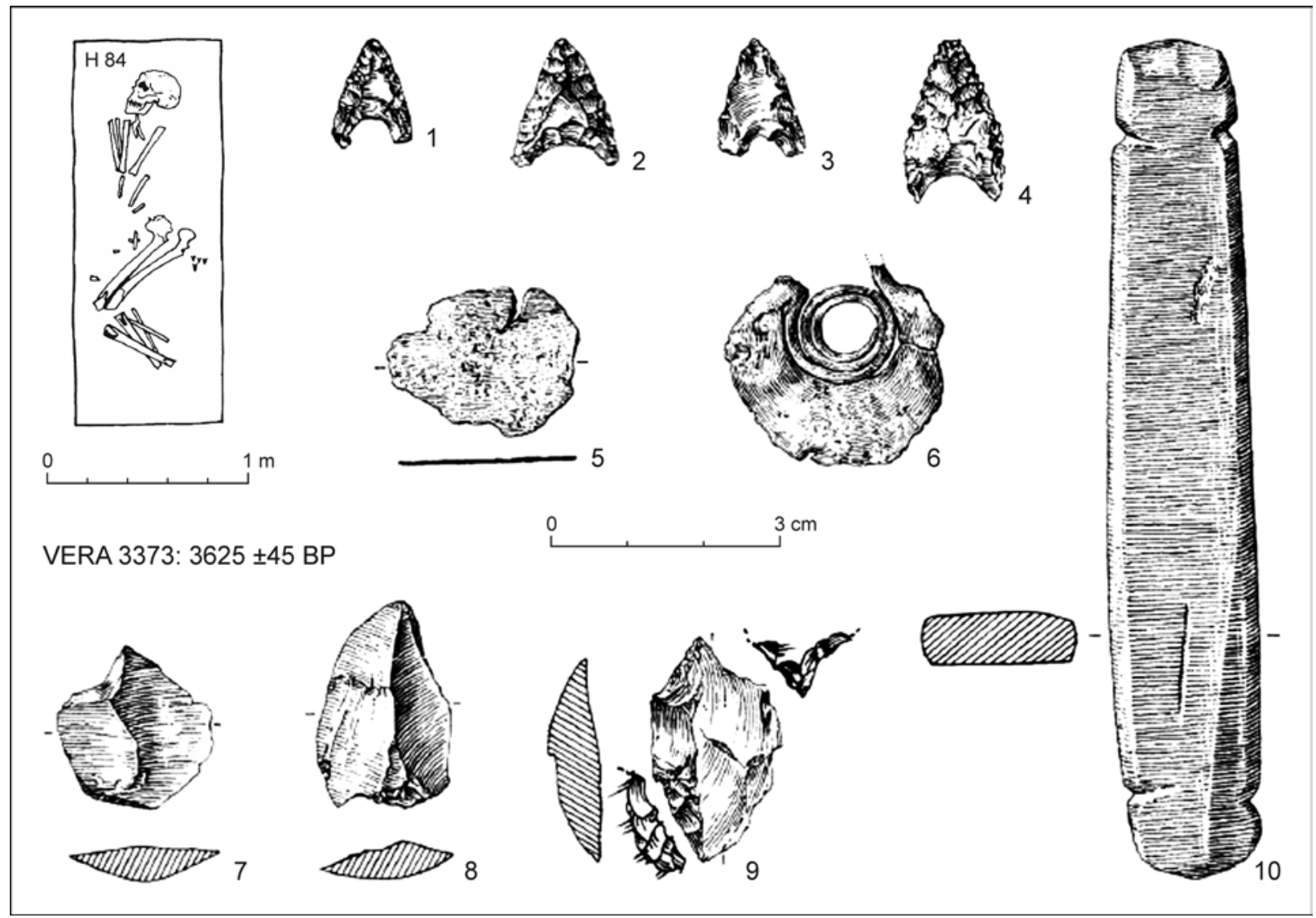

Obr. 21. Holešov-Zdražilovsko. Inventář H 84 - starší nitranská fáze (NK3). Podle Ondráček/Šebela 1985, upraveno.

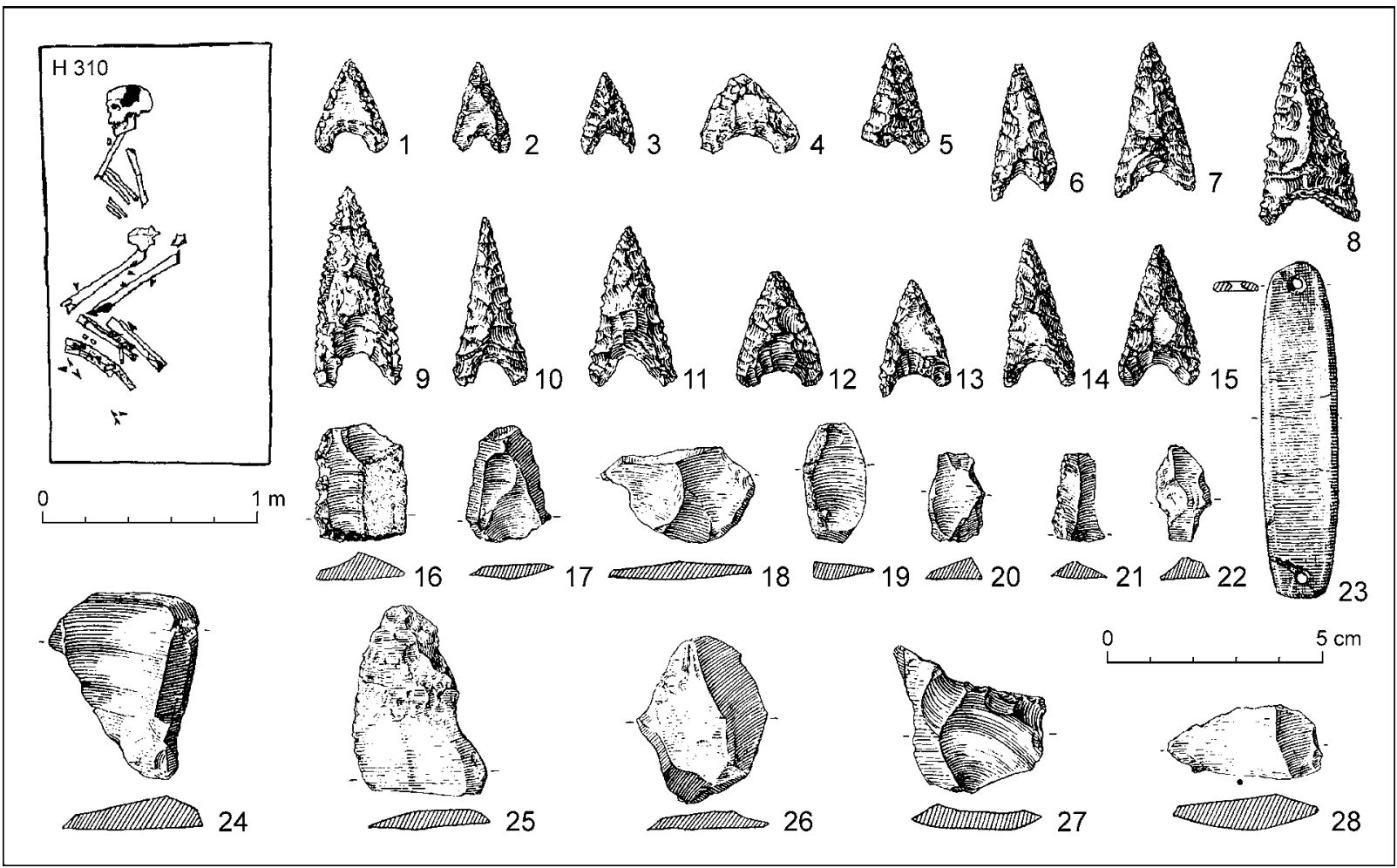

Obr. 22. Holešov-Zdražilovsko. Inventář H 310 - starší nitranská fáze (NK3). Podle Ondráček/Šebela 1985, upraveno. 


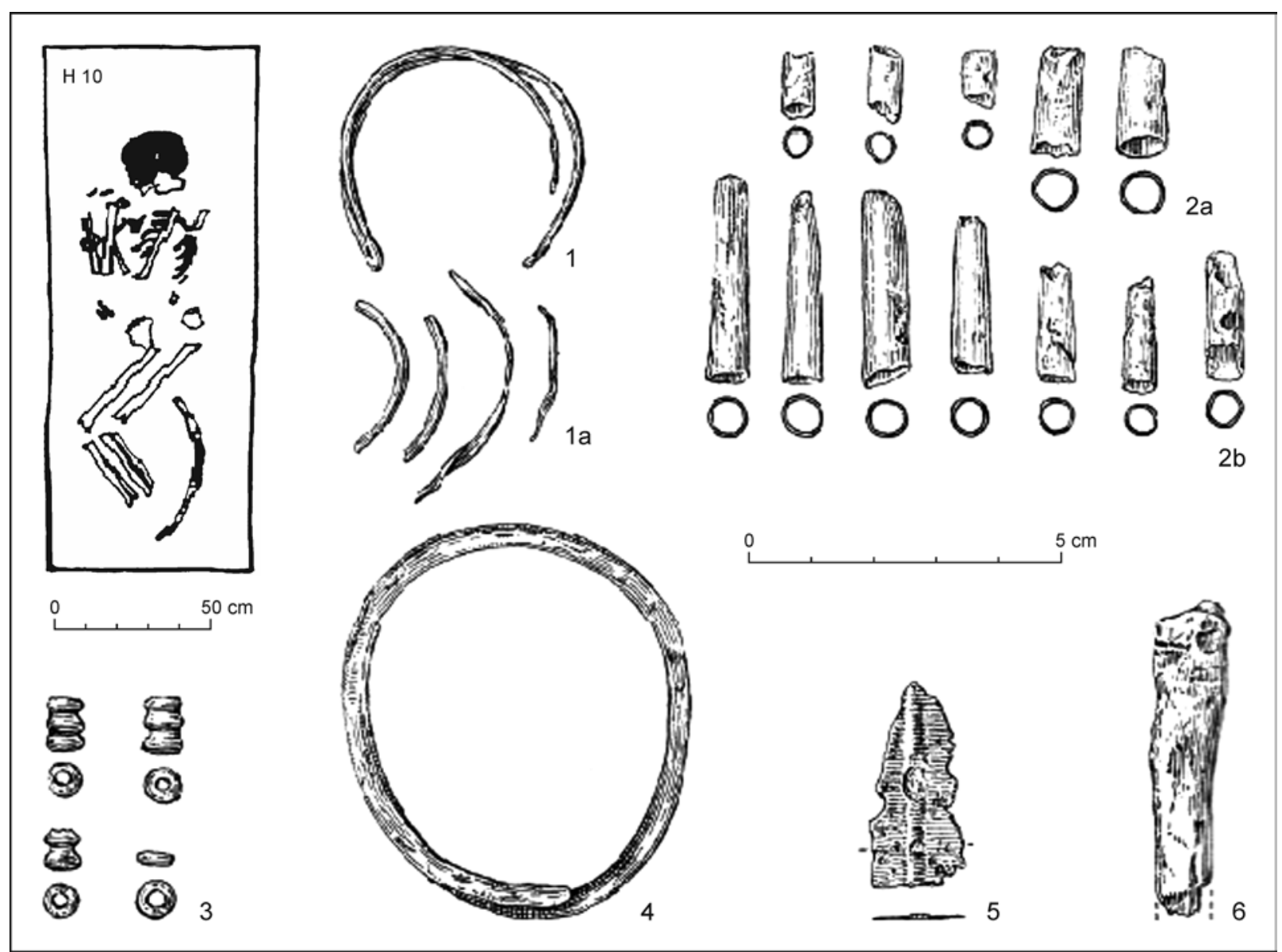

Obr. 23. Holešov-Zdražilovsko. Inventář H 10 - klasická nitranská fáze (NK4). Podle Ondráček/Šebela 1985, upraveno.

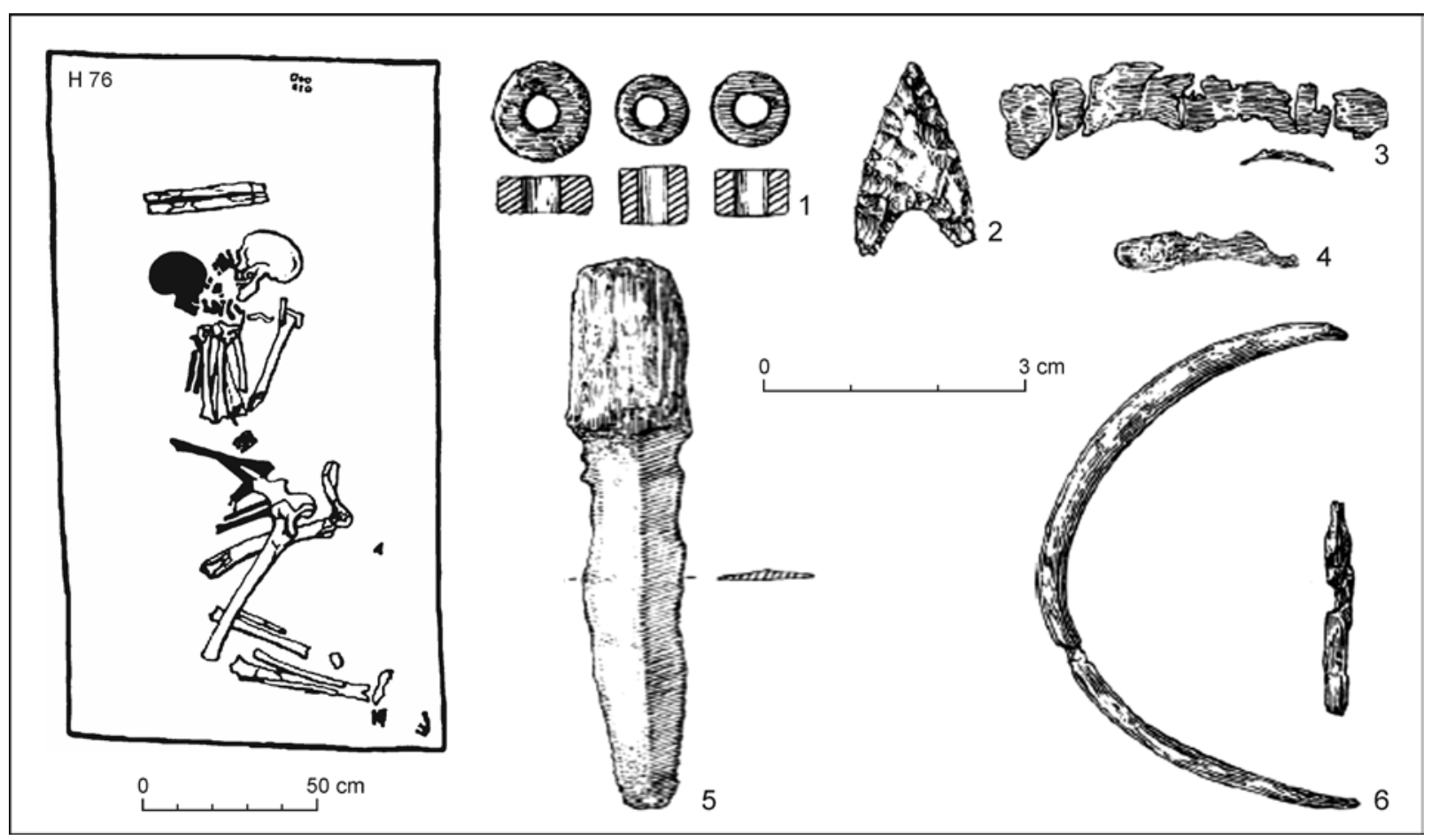

Obr. 24. Holešov-Zdražilovsko. Inventář H 76 - klasická nitranská fáze (NK4). Podle Ondráček/Šebela 1985, upraveno. 


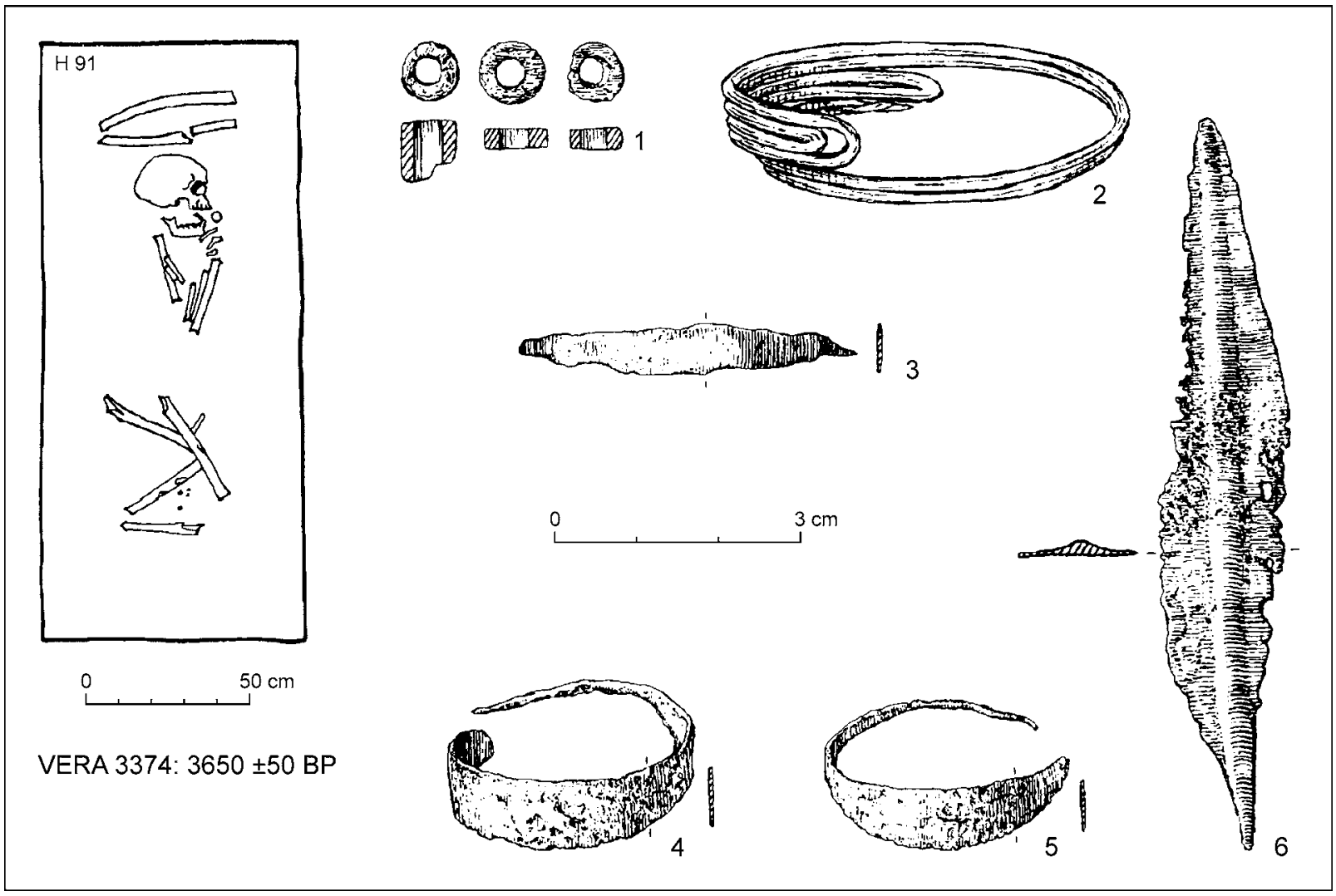

Obr. 25. Holešov-Zdražilovsko. Inventář H 91 - klasická nitranská fáze (NK4). Podle Ondráček/Šebela 1985, upraveno.

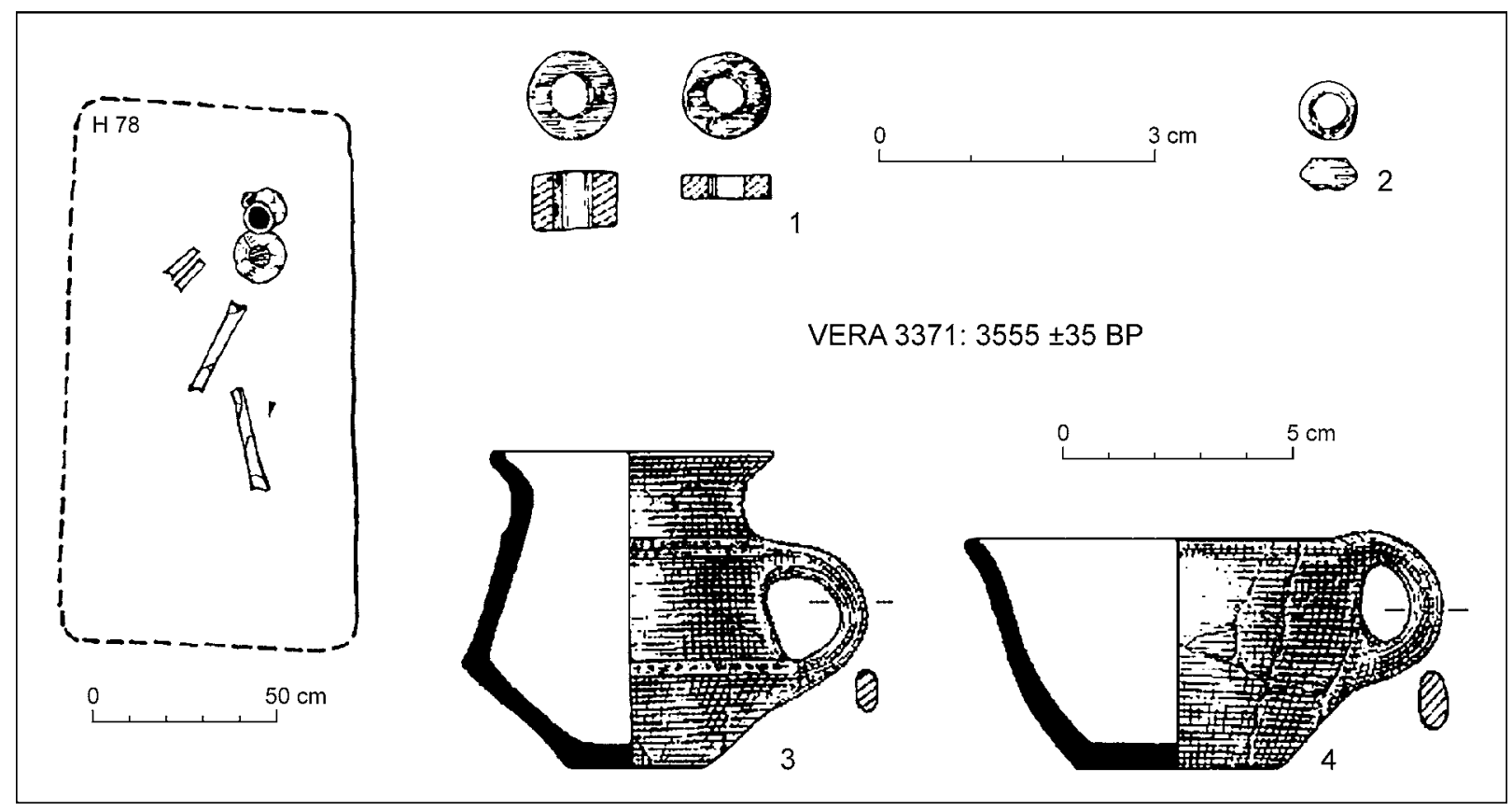

Obr. 26. Holešov-Zdražilovsko. Inventář H 78 - poklasická nitranská fáze (NK5). Podle Ondráček/Šebela 1985, upraveno. 


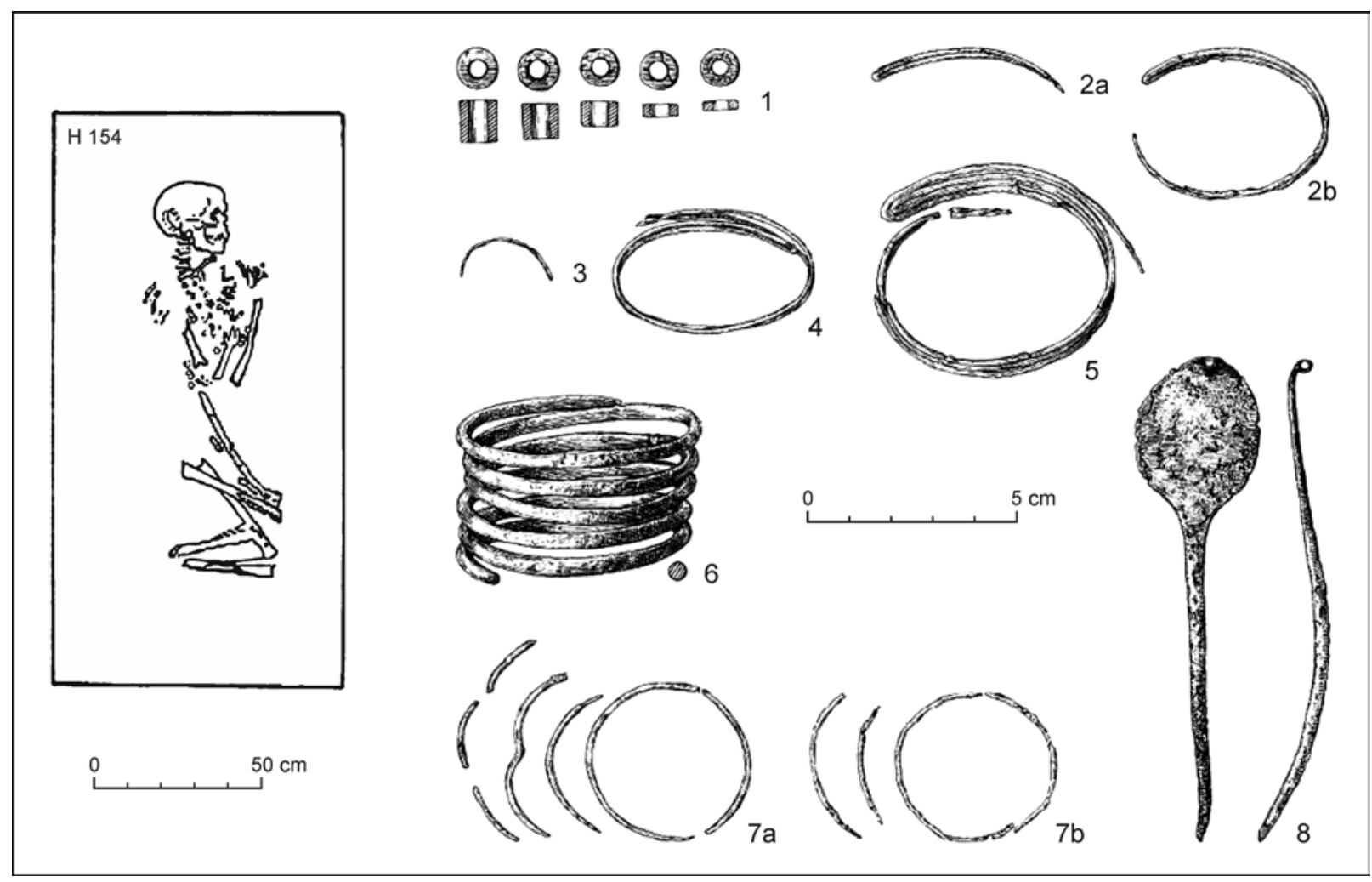

Obr. 27. Holešov-Zdražilovsko. Inventář H 154 - poklasická nitranská fáze (NK5). Podle Ondráček/Šebela 1985, upraveno.

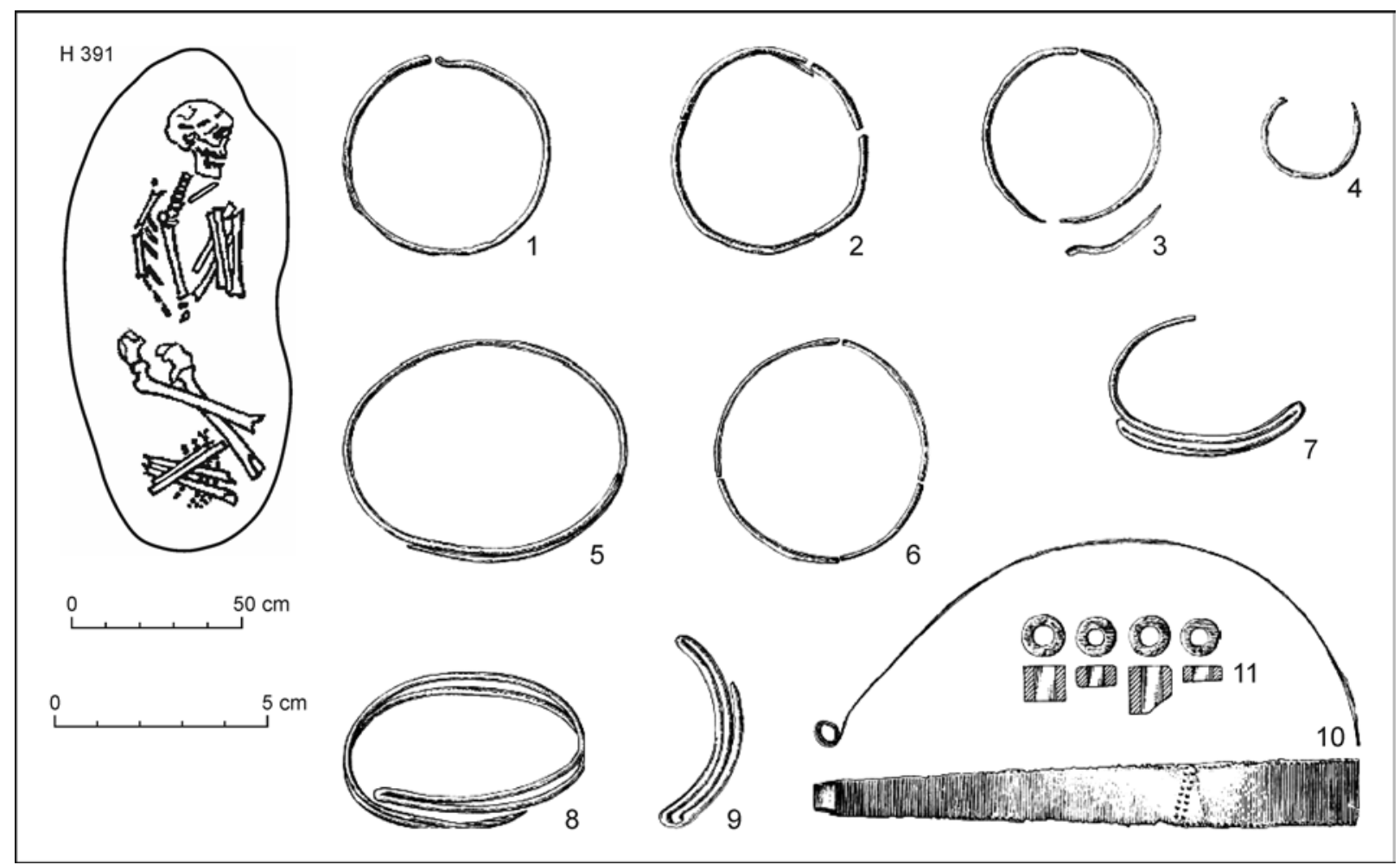

Obr. 28. Holešov-Zdražilovsko. Inventář H 391 - poklasická nitranská fáze (NK5). Podle Ondráček/Šebela 1985, upraveno. 


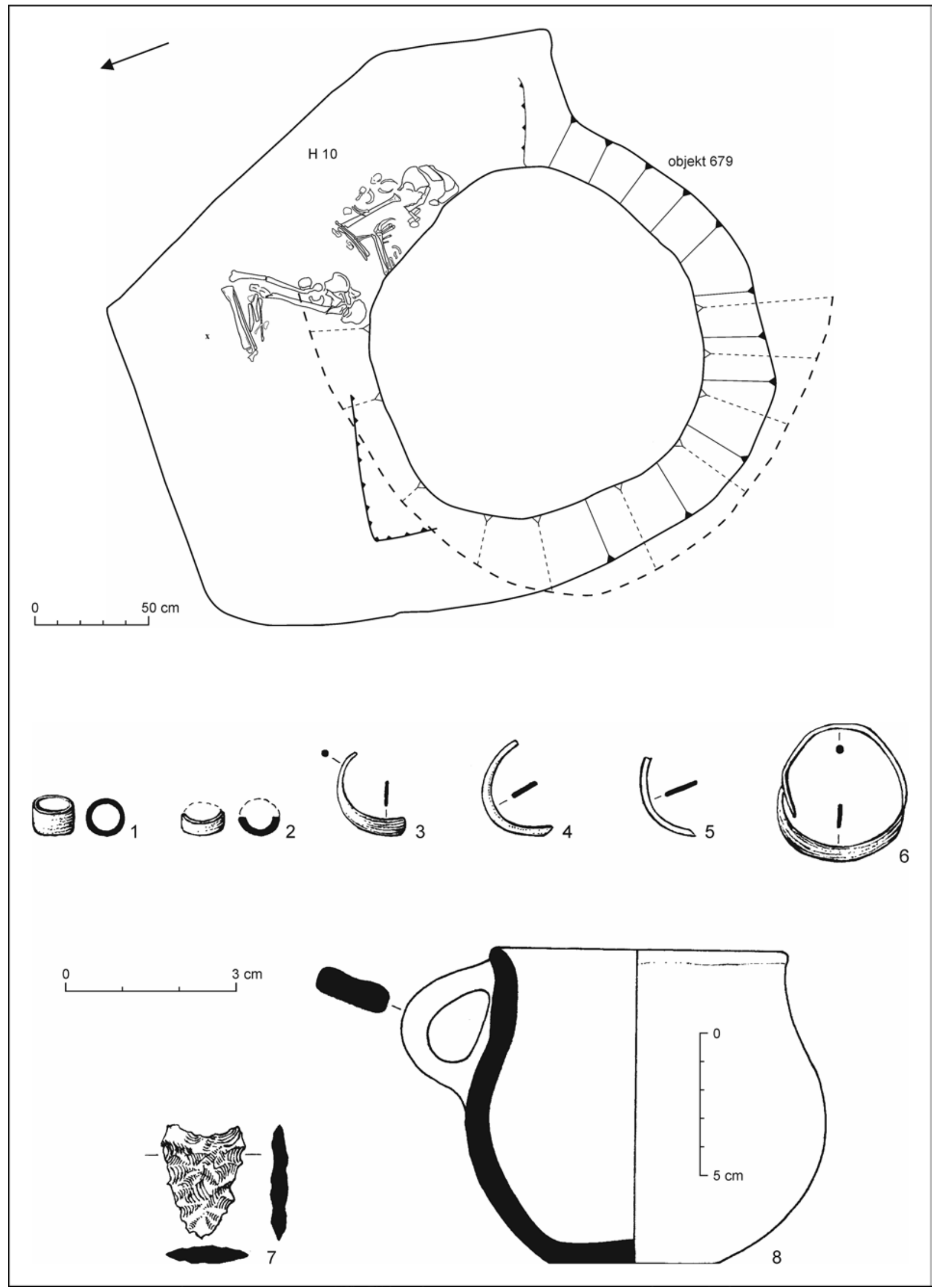

Obr. 29. Přerov-Předmostí 7-Malé Předmostí H10. Inventář hrobu protonitranské fáze (NK1). Podle Peška/Hadrava/Šín 2019, upraveno. 


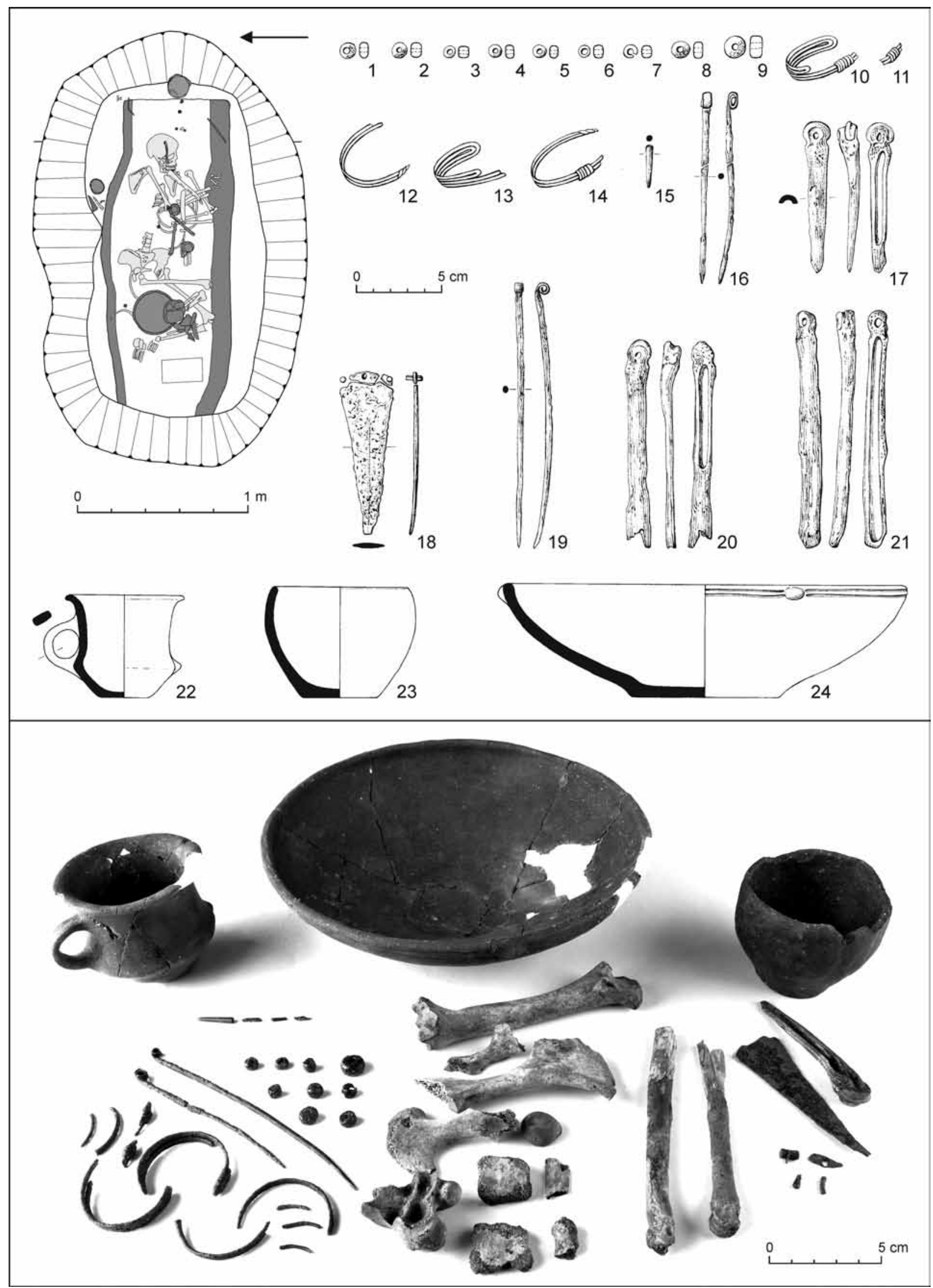

Obr. 30. Osek nad Bečvou 2-Nademlýnice. Půdorys hrobové jámy s uložením kostry dospělé ženy a dvou dětí se veškerou výbavou. Podle Peška/Tajer 2015b, upraveno. 


\section{Vybraní reprezentanti jednotlivých fází}

Novým př́mým dokladem vzájemné synchronizace nitranské a (proto)únětické kultury se stal hrob mladého jedince (12-15 let) mužského pohlaví z Přerova-Předmostí 7 (Peška/Hadrava/Šín 2019) s protoúnětickým hrnkem, tři prsteny a vlasovou ozdobou ve tvaru hladkého vrbového listu, dvojicí kostěných válcovitých korálků a hrotem šípu (obr. 29). Na základě vcelku starobylého hrnku (typ Trausdorf-Leithaprodersdorf 2) a vysokého absolutního data DeA-189093762 \pm 32 BP, 2275 (9,7\%) 2255, $2209(58,5 \%) 2136 \mathrm{cal} \mathrm{BC} \mathrm{(1} \mathrm{\sigma )} \mathrm{a} 2288(83,5 \%)$ 2126, 2090 (11,9 \%) 2044 cal BC (2 б), patřící na Moravě $\mathrm{k}$ nejstarším, jsme nakloněni celek zařadit do protonitranské fáze.

Příkladným reprezentantem poklasické fáze vývoje je zajímavý následný hrob ženy a dvou malých dětí z Oseku nad Bečvou 2 (Peška/Tajer 2015b) $\mathrm{s}$ jasným epišňůrovým pohřebním ritem, avšak již zcela „únětizovanou“ výbavou v čele s keramikou předklasické fáze ÚK, rozlomenou triangulární dýkou, dvojicí jehlic s hlavicí svinutou v očko, jantarovými korálky, včetně takových shodných detailů jakými je ovinutí několika vlasových Noppenringů jednoduchým drátkem (obr. 30). Tento jev jsme $\mathrm{v}$ únětickém prostředí pozorovali zatím pouze u ozdob z hrobů předklasické fáze. Absolutní data (byt’ vůči stratigrafii $\mathrm{v}$ poněkud opačném modu), pohybující se po kalibraci v pásmu 1951-1868 BC, chronologickou pozici pohřbu potvrzují. Na základě stronciové analýzy také víme, že dospělá žena pocházela z oblasti severně Vysokých Tater, čili jižního či jihovýchodního Polska.

Dříve získaný (Štramberk-jeskyně Čertova díra), ale především nově objevovaný a postupně zveřejňovaný materiál EPKK severně od Moravské brány má mnoho společných rysů (např. typologie i technologie keramiky, broušené industrie etc.) a má blíže $\mathrm{k}$ mierzanovické kultuře v Malopolsku, ale především na Horním Slezsku než k vlastní nit- ranské na Moravě a na Slovensku, takže navrhujeme označovat epišňůrové nálezy $\mathrm{z}$ tohoto regionu jako mierzanovické se stejným vnitřním členěním. Prokázat přímé propojení s materiálem z polské části Horního Slezska nebude patrně žádný problém. Nálezy a lokality z prostoru Moravské brány a na jih od ní, včetně JZ Slovenska, označovat jako nitranské s tím, že je zjevná vysoká míra podobnosti a společný genetický základ obou složek EPKK.

\section{ZÁVĚR}

Aplikujeme-li získaná absolutní data do námi navrženého schématu (část dat je zcela zjevně chybná), je výsledkem jisté seskupení dat (clustery), které se částečně (někde dost) překrývají, ale $\mathrm{v}$ zásadě mají tendenci růstu od relativně starších po mladší $\mathrm{v}$ rámci skupin, tj. jednotlivých fází (výjimkou jsou data z nejmladších fází, může se na tom podílet i jejich nedostatek či silná selekce), což by potvrzovalo správnost postupu a našich závěrů. Jak už bylo naznačeno, jednotlivé fáze není možné vymezit ostrou hranicí nebo předělem a zřejmě bude nejen pro jednotlivé kultury, ale i časová období v jejich rámci platit minimálně částečné překrývání počátečních a koncových etap, jak je tomu i u jiných entit.

Kombinace několika na sobě nezávislých metod typochronologie a mnohorozměrné statistiky nepřinesla jednoznačné a nediskutovatelné výsledky (s tím souvisí nízká kvalita dat do statistik zanesených), ukázala nicméně na jisté společné znaky určitých jasných tendencí ve vývoji materiální kultury zkoumané entity, které se vzájemně doplňují, avšak nevylučují. Navrženou koncepci interního dělení nitranské, potaženo mierzanovické kultury na našem území považujeme za prokázanou a dobře zdůvodnitelnou. To však neznamená v budoucnu, $\mathrm{v}$ důsledku nových závažných nálezových kontextů a například hustší frekvence absolutních dat, její korekce, doplňování nebo zjemňování.

\section{LITERATURA}

Bátora 2000 - J. Bátora: Das Gräberfeld von Jelšovce/Slowakei. Ein Beitrag zur Frühbronzezeit im nordwestlichen Karpatenbecken. Teil 1, 2. Kiel 2000.

Bátora 2018 - J. Bátora: Slovensko v staršej dobe bronzovej. Bratislava 2018.

Bátora/Vladár 2015 - J. Bátora/J. Vladár: Kultúry staršej doby bronzovej. In: V. Furmánek (zost.): Staré Slovensko 4. Doba bronzová. Nitra 2015, 21-41.

Benkovsky-Pivovarová 1999 -Z. Benkovsky-Pivovarová: Zum Begriff Nitra-Gruppe bzw. Kultur. Pravěk. Nová řada 8, 1998, 141-150.
Benkovsky-Pivovarová/Chropovský 2015 - Z. Benkovsky-Pivovarová/B. Chropovský: Grabfunde der frühen und beginnenden mittleren Bronzezeit in der Westslowakei. Nitra 2015.

Berkovec/Peška 2005a - T. Berkovec/J. Peška: Hulín (okr. Kroměříž). Přehled výzkumu 46, 2004, 2005, 231.

Berkovec/Peška 2005b - T. Berkovec/J. Peška: Starobronzová sídliště a pohřebiště v Hulíně-U Isidorka. In: M. Bém/ J. Peška (ed.): Ročenka 2004. Olomouc 2005, 44-68.

Berkovec/Peška 2006 - T. Berkovec/J. Peška: Hulín (okr. Kroměříž). Přehled výzkumů 47, 2006, 127, 128. 
Brower/Kile 1988 - J. C. Brower/K. M. Kile: Seriation of an original data matrix as applied to palaeoecology. Lethaia 21, 1988, 79-93.

Budinský-Krička 1965 - V. Budinský-Krička: Pohrebisko s kultúrou neskorej šnúrovej keramiky vo Veselom. Slovenská archeológia 13, 1965, 51-106.

Buchvaldek 1963 - M. Buchvaldek: K tzv. „zlotskému“ typu na Moravě a jz. Slovensku. In: Sborník II. Františku Vildomcovi k pětaosmdesátinám. Brno, 1963, 34-38.

Dvorský 1914 - K. Dvorský: Kostra („,skrčka“) nalezená u Strážnice. In: Vlastivěda moravská II. Místopis Moravy II. Hradištský kraj, Strážnický okres. Brno 1914, 485-487.

Furmánek/Veliačik/Vladár 1991 - V. Furmánek/L. Veliačik/ J. Vladár: Slovensko v dobe bronzovej. Bratislava 1991.

Hammer/Harper/Ryan 2001 - Ø. Hammer/D. A. T. Harper/ P. Ryan: PAST. Paleontological Statistics Software Package for Education and Data Analysis. Palaeontologia Electronica 4/1, 2001, 1-9.

Holčík/Komenda 2015 - J. Holčík/M. Komenda (ed.): Matematická biologie: e-learningová učebnice. Brno 2015. Dostupno na: https://portal.matematickabiologie.cz/

Horsák 1941 - A. Horsák: Výkopy v Kunovicích, Derfli, Míkovicích, Ostrožské Nové Vsi, Starém Městě. Sborník velehradský 12, 1941, 88-92.

Hrubý 1948 - V. Hrubý: Z pravěku středního Pomoraví. Stručný přehled nejstarších dějin a archeologických problémů Uh. Hradištska. Vlastivědný sborník okresu uherskohradištského II. Uherské Hradiště 1948.

Hrubý a j. 1956 - V. Hrubý/V. Hochmannová/F. Kalousek/ J. Pavelčík: Přehled nejuýznamnějších archeologických lokalit Gottwaldovského kraje. Studie Krajského muzea v Gottwaldově a práce externích pracovníků 1 . Gottwaldov 1956.

Kadrow/Machnikowie 1992 - S. Kadrow/J.-A. Machnikowie: Iwanowice, stanovisko Babia Góra II. Cmentarzysko z wczejnego okresu epoki brazu. Kraków 1992.

Kadrow/Machnik 1997 -S. Kadrow/J. Machnik: Kultura mierzanowicka. Chronologia, taksonomia i rozwój przestrzenny. Kraków 1997.

Kadrow/Peška 1999 - S. Kadrow/J. Peška: Älteste frühbronzezeitliche Siedlungen in Mähren und der Anfang des Epischnurkeramischen karpatenländischen Kulturkreises. In: J. Bátora/J. Peška (Hrsg.): Aktuelle Probleme der Erforschung der Frühbronzezeit in Böhmen und Mähren und in der Slowakei. Nitra 1999, 33-40.

Kadrow/Peška/Vitula 2000 - S. Kadrow/J. Peška/P. Vitula: Siedlung des Epischnurkeramischen karpatenländischen Kulturkreises in Přáslavice in Mähren. In: S. Kadrow (ed.): A Turning of Ages. Jubilee Book Decidated to Professor Jan Machnik on his $70^{\text {th }}$ Anniversary. Kraków 2000, 301-312.

Kaňáková/Šmerda/Nosek 2016 - L. Kaňáková/J. Šmerda/V. Nosek: Analýza kamenných projektilů z pohřebiště starší doby bronzové Hroznová Lhota. Traseologie a balistika. Archeologické rozhledy 68, 2016, 163-201.

Kolbinger 2012 - D. Kolbinger: 50 let mých povrchových výzkumü na východním Kroměřížsku. Rejstř́k záznamů o provedených výzkumech v letech 1960-2010. Zprávy České Archeologické Společnosti. Supplementum 83. Praha 2012.

Kovářová 1928 - L. Kovářová: Únětický nález v Drahlově. Časopis Vlasteneckého musejního spolku v Olomouci 40, 1928,145

Lê/Josse/Husson 2008 - S. Lê/J. Josse/F. Husson: FactoMineR: A Package for Multivariate Analysis. Journal of Statistical
Software 25/1, 2008, 1-18

DOI: https://doi.org/10.18637/jss.v025.i01

Lichardus/Vladár 1997 - J. Lichardus/J. Vladár: Frühe und mittlere Bronzezeit in der Südwestslowakei. Forschungsbeiterg von Anton Točík. Slovenská archeológia 45, 1997, 221-352.

Machnik 1960 - J. Machnik: Ze studiów nad kulturą keramiky sznurowej w Karpatach Polskich. Acta Archaeologica Carpathica 2, 1960, 55-86.

Machnik 1963 - J. Machnik: Uwagi o związkach i chronologii niektóych znalezisk kultury ceramiki sznurowej w Karpatach. Acta Archaeologica Carpathica 4, 1963, 91-107.

Machnik 1967 - J. Machnik: Stosunki kulturowe na przełomie neolitu i epoki brązu w Małopolsce (na tle przemian w Europie Środkowej). In: W. Hensel (red.): Materiaty do prehistorii ziem Polskich 3. Epoka brązu 1. Warszawa 1967.

Machnik 1977 - J. Machnik: Frühbronzezeit Polens (Übersicht über die Kulturen und Kulturgruppen). Wrocław 1977.

Maška 1907 - K. J. Maška: Obrázky z pravěku moravského (Šolcova moravská čitanka). Telč 1907.

Menoušková/Fikrle 2019 - D. Menoušková/M. Fikrle: Měděné artefakty z eneolitu a starší doby bronzové z Uherskohradištska. Slovenská archeológia 67, 2019, 1-18.

Ondráček 1963 - J. Ondráček: Nálezy mierzanovicko-nitranského typu na Moravě. Archeologické rozhledy 15, 1963, 405-415.

Ondráček 1972 - J. Ondráček: Pohřebiště nitranské skupiny v Holešově. Archeologické rozhledy 24, 1972, 168-172, 233-235.

Ondráček 1993 - J. Ondráček: Nitranská skupina. In: V. Podborský a kolektiv: Pravěké dějiny Moravy. Vlastivěda Moravská. Země a lid 3. Brno 1993, 258-262.

Ondráček/Šebela 1985 - J. Ondráček/L. Šebela: Pohřebiště nitranské skupiny v Holešově (katalog nálezů). Studie Muzea Kroměřížska 85. Gottwaldov 1985.

Palliardi 1893 - J. Palliardi: Hroby se skrčenými kostrami na Znojemsku. Časopis Vlasteneckého musejního spolku v Olomouci 10, 1893, 129-142.

Peška 1983 - J. Peška: Oblast východní Moravy na konci eneolitu a ve starší době bronzové. Diplomové práce. Bratislava 1983. Nepublikováno.

Peška 1989 - J. Peška: Die Anfänge der Bronzezeit in Ostmähren. In: Das Äneolithikum und die früheste Bronzezeit (C ${ }^{14}$ 3000-2000 b.c.) in Mitteleuropa: kulturelle und chronologische Beziehungen. Acta des XIV. Internationalen Symposiums Prag - Liblice 20.-24. 10. 1986. Praehistorica XV. Praha 1989, 193-199.

Peška a d. 2005 - J. Peška/T. Berkovec/M. Hložek/P. Krupa/ T. Tpjek/E. Drozdová/Z. Koldínská/M. Králík/A. Selucká: Dosavadní výsledky mezioborové spolupráce na nálezech ze starší doby bronzové v Hulíně-U Isidorka. In: M. Bém/J. Peška (ed.): Ročenka 2004. Olomouc 2005, 68-93.

Peška 2009 - J. Peška: Protoúnětické pohřebiště z Pavlova. Olomouc 2009.

Peška 2012 - J. Peška: Frühbronzezeitliche Gräberfelder von Hulín in Ostmähren (Tschechische Republik). In: D. Bérenger/J. Bourgeois/M. Talon/S. Wirth (Hrsg.): Gräberlandschaften der Bronzezeit. Paysages funéraires de l'âge du Bronze. Internationales Kolloquium im LWL-Museum für Archäologie in Herne vom 15. bis 18. Oktober 2008. Bodenaltertümer Westfalens 51. Münster 2012, 487-498.

Peška 2013 - J. Peška: Kultureinflüsse und Kontakte Ostmährens am Anfang der Bronzezeit. In: M. Bartelheim/ J. Peška/J. Turek (ed.): From Copper to Bronze. Cultural and 
Social Transformations at the Turn of the $3^{\text {rd }} / 2^{\text {nd }}$ Millenia B.C. in Central Europe. Gewidmet PhDr. Václav Moucha, CSc. anlässlich seines 80 . Geburtstages. Beiträge zur Ur- und Frühgeschichte Mitteleuropas 74. Langenweissbach 2013, 81-100.

Peška 2016 - J. Peška: Ke struktuře epišňůrového osídlení v Hulíně a jeho okolí. In: M. Popelka/R. Šmidtová/ P. Burgert/J. Jílek (ed.): ... tenkrát na východě... Sborník k 80. narozeninám Víta Vokolka. Praehistorica 33/1-2. Praha 2016, 315-336. DOI: https://doi.org/10.14712/25707213.2017.26

Peška/Hadrava/Šín 2019 - J. Peška/V. Hadrava/L. Šín: Pozoruhodný hrobový celek $\mathrm{z}$ počátku doby bronzové na lokalitě Přerov-Předmostí 7, trat' Malé Předmostí, okr. Přerov. In: M. Kršková/J. Peška (ed.): Ročenka 2018. Olomouc 2019, 109-130.

Peška/Šebela 1992 - J. Peška/L. Šebela: Funde der Chłopice-Veselé-Gruppe in Mähren und ihre Stellung in der Endphase des Spätäneolithikums. In: Die kontinentaleuropäischen Gruppen der Kultur mit Schnurkeramik. Die kontinentaleuropäischen Gruppen der Kultur mit Schnurkeramik. Praehistorica XIX. Praha 1992, 131-141.

Peška/Tajer 2014 - J. Peška/A. Tajer: Osek nad Bečvou 1 epišňůrová osada ze starší doby bronzové v Moravské bráně. In: M. Bém/J. Peška (ed.): Ročenka 2013. Olomouc 2014, 134-159.

Peška/Tajer 2015a - J. Peška/A. Tajer: Problematika epišňůrových sídlišṫ na Moravě - stav poznání. In: J. Bátora/ P. Tóth (ed.): Ked' bronz vystriedal med'. Zborník príspevkov z XXIII. mezdinárodného sympozia „Staršia doba bronzová v Čechách, na Morave a na Slovensku“, Levice 8.-11. októbra 2013. Archaeologica Slovaca Monographiae 18. Bratislava - Nitra 2015, 77-104.

Peška/Tajer 2015b - J. Peška/A. Tajer: Starobronzový pohřeb z Oseku nad Bečvou 2 na východní Moravě. In: M. Bém/ J. Peška (ed.): Ročenka 2014. Olomouc 2015, 67-99.

Raup/Crick 1979 - D. M. Raup/R. E. Crick: Measurement of faunal similarity in paleontology. Journal of Paleontology 53, 1979, 1213-1227.

$R$ Core Team 2019-R: A Language and Environment for Statistical Computing. Dostupno na: https://www.R-project.org/

Schimerová 2014 -E. Schimerová: Sídliště a pohřebiště nitranské kultury v Hulíně 3 . Diplomová práce. Filosofická fakulta Univerzity Komenského. Bratislava 2014. Nepublikováno.

Struhala 1951 - B. Struhala: Pohřebiště ze starší doby bronzové u Holešova na Moravě, Archeologické rozhledy 3, 1951, 33, 34.

Stuchlík 2000 - S. Stuchlík: Únětická kultura a epišňůrový kulturní okruh na Moravě. In: J. Rydzewski (red.): 150 lat Muzeum Archeologicznego w Krakowie. Kraków 2000, 281-296.

Rukopis prrijat 19. 10. 2020

Translated by Jana Kličová

doc. PhDr. Jaroslav Peška, PhD.

Archeologické centrum Olomouc

U Hradiska $42 / 6$

CZ - 77900 Olomouc

peška@ac-olomouc.cz
Stuchlík 2001 - S. Stuchlík: Die Besiedlung Ostmährens durch die Aunjetitzer Kultur und den epischnurkeramischen Komplex zu Beginn der Bronzezewit. In: A. Lippert/M. Schultz/S. Shennana/M. Teschler-Nicola (ed.): Mensch und Umwelt während des Neolithikums und Frühbronzezeit in Mitteleuropa. Internationale Workshop vom 9.-12. November 1995, Wien. Rahden/Westf. - Wien 2001, 221-230.

Stuchlík 2014 - S. Stuchlík: Česko-polské kontakty a počátek doby bronzové. Časopis Moravského muzea. Vědy společenské 99, 2014, 37-50.

Svešnikov 1974 - I. K. Svešnikov: Istorija naselenija Perettkarpattja, Podillja i Volyni v kinci III - na počatku II tisjačolittja do našoj ery. Kyjiv 1974.

Šebela 2014 - L. Šebela: Cemetery in Opava-Kylešovice and the question of its chronology. In: J. Kopacz/A. Přichystal/ L. Šebela (ed.): Lithic chipped industry of the young Eneolithic in Moravia and Czech Silesia. Spisy Archeologického ústavu AV ČR Brno 46. Brno 2014, 152-166.

Šebela a d. 1990 - L. Šebela/J. Peška/V. Janák/E. Grepl: K otázce epišňůrového kulturního komplexu na východní Moravě. Archaeologia Juvenis 1, 1990, 11-27.

Šmejda 2003 - L. Šmejda: Hlavní osy variability pohřebního ritu na lokalitě z mladšího eneolitu a starší doby bronzové u Holešova, okr. Kroměříž. In: L. Šmejda/P. Vařeka (red.): Sedmdesát neustupných let. Sborník k životnimu jubileu prof. E. Neustupného. Plzeň 2003, 179-198.

Šmíd 2012 - M. Šmíd: Sídliště ze starší doby bronzové v průmyslové zóně u Holešova. Pravěk. Nová řada 20, 2012, 15-38.

Tajer 2009 - A. Tajer: Hulín (okr. Kroměříž). Přehled výzkumu 50, 2009, 286.

Tihelka 1953 - K. Tihelka: Moravská únětická pohřebiště. Památky archeologické 44, 1953, 229-328.

Točík 1956 - A. Točík: Staršia a stredná doba bronzová na juhozápadnom Slovensku. In: Referáty Liblice 1955. Liblice 1956, 24-46.

Točík 1963 - A. Točík: Die Nitra Gruppe. Archeologické rozhledy 15, 1963, 716-774.

Točík 1979 - A. Točík: Výčapy-Opatovce a d'alšie pohrebiská zo staršej doba bronzovej na juhozápadnom Slovensku. Materialia Archaeologica Slovaca 1. Nitra 1979.

Wankel 1889 - J. Wankel: Náklo a Př́íkazy na Moravě. Časopis Vlasteneckého musejního spolku v Olomouci 6, 1889, 49-58, 97-105.

Wei/Simko 2017 - T. Wei/V. Simko: R package "corrplot": Visualization of a Correlation Matrix. Dostupno na: https://github.com/taiyun/corrplot

Wickham 2016 - H. Wickham: ggplot2: Elegant Graphics for Data Analysis. New York 2016. Dostupno na: http://ggplot2.tidyverse.org

doc. RNDr. Miroslav Králík, PhD.

Ústav antropologie

Přírodovědecká fakulta, Masarykova univerzita Brno

Kotlářská 267/2

CZ - 61137 Brno

kralik@sci.muni.cz 


\title{
Internal Periodization of the Epicorded Carpathian Cultural Complex in Moravia and Silesia
}

\author{
Jaroslav Peška - Miroslav Králík
}

\author{
SUMMARY
}

\begin{abstract}
Epi-corded finds from the territory of East Moravia, discovered at the end of the $19^{\text {th }} \mathrm{c}$. and in the beginning and first half of the $20^{\text {th }} \mathrm{c}$. (Strážnice, Př́k kazy, Drahlov, Uherské Hradiště-Sady, Ostrožská Nová Ves), were not paid any systematic attention, maybe except the cemetery at Holešov. The network of sites, mostly comprising small or large inhumation cemeteries and less frequently flatland settlements, gradually grows up, also on the MoravianSilesian border (Opava-Kylešovice, Opava-Kateřinky, Opava-Vávrovice). Today we already can take into consideration 72 sites (unverified sites of D. Kolbinger, reclassification from Únětice Culture), located within a narrow stripe of land on the right bank of the river Morava (Fig. 1; 2). The original concept of Epi-corded development with two components - Chłopice-Veselé and Nitra/Mierzanowice Culture - is today replaced with regard to material, stratigraphy and absolute chronology by the unified Nitra/ Mierzanowice Culture, which is considered to represent the ECCC on the studied territory. On the basis of current knowledge of the typo-chronology of material culture (grave goods) and independent methods of multidimensional statistics (correspondence analysis, principal component analysis, principal coordinates analysis, correlation and seriation) we have identified several clear development tendencies (the oldest corded ware, willow-leaf industry, hunter-warrior equipment of male graves through to metal wire and sheet industry accompanied by Únětice pottery of old and pre-classical forms), which enable us to preliminarily distinguish 6 chronological horizons of the burials at Holešov (including the classical phase of Únětice Culture). In accordance with Lesser Poland (probably also valid for Upper Silesia), but in contrast to SW Slovakia (most recently Bátora 2018, 71 sq.), we suggest a new internal division of Nitra Culture into five phases with simple characteristics: Proto-Nitra Culture NC1 (S-profiled mugs decorated with cord imprints in the form of
\end{abstract}

Fig. 1. Map of settlement by Nitra Culture in Moravia and Silesia.

Fig. 2. Map of settlement by Nitra culture, with unverified localities according Kolbinger 2012 and unclassified from Únětice Culture. Legend: $a$ - Nitra Culture; $b$ - unverified sites; c - Únětice Culture.

Fig. 3. Holešov-Zdražilovsko. Frequency of occurrence of important grave goods in individual burial horizons at the burial ground of the Nitra culture.

Fig. 4. Scatterplot of scores of variables (grave goods) on correspondence axes 3 and 4 - results of Correspondence Analysis of the analyzed incidence matrix. multiple horizontal lines, axe-hammers similar to those of Corded Ware Culture, wrist-guards, arrowheads, cylindrical bone beads, willow-leaf industry - plain?), Early Nitra Culture NC2 (undecorated and corded pottery: horizontal and vertical lines, loops, decoration of the whole surface inclusive of handles, relief appliqués, Proto-Únětice pottery, arrowheads, wrist-guards, bone beads, plain and ribbed willow-leaf industry, neck ring, bracelets), Old Nitra Culture NC3 (distinctive pottery, advanced Proto-Únětice and Early Únětice forms, wrist-guards, arrowheads, boar tusks, dagger of type Holešov, cylindrical beads, faience beads, plain and ribbed willow-leaf industry, ornaments from simple and double wire), Classical Nitra Culture NC4 (undecorated Nitra pottery, early Únětice forms, bone and faience beads, Dentalium shells, bone and antler tools, willow-leaf industry, ornaments from double wire with reversed loop, spiral rolls, wire industry, spiral arm rings, disc-headed pins, sheet-metal diadems, typologically younger daggers - ornamented), introducing selected representatives of several phases (Přerov-Předmostí 7 H 10 Proto-Nitra Culture, Osek nad Bečvou 2 and ŠtramberkČertova díra - Post-classical NC). Since the material from the territory north of the Moravian Gate is very similar to finds from Upper Silesia and Lesser Poland, we suggest to classify this material as Mierzanowice Culture, whereas the material from the territory south of the Moravian Gate to as far as SW Slovakia should be classified as Nitra Culture. When we apply a modest series of absolute dates $(n=23)$ to the suggested structure, we can observe some degree of their overlap with a growing tendency from older to younger within the distinguished phases. This development is disrupted by indications of certain regression in the later period (Classical and Post-classical NC), whose reasons cannot be completely clarified so far. The number of dates, however, is too small and the quality of results is not necessarily always guaranteed.

Fig. 5. Scatterplot of scores of cases (graves) on correspondence axes 3 and 4 - results of Correspondence Analysis of the analyzed incidence matrix.

Fig. 6. Scatterplot of scores of PC1 and PC2 of the Principal Component Analysis.

Fig. 7. Scatterplot of scores of PCo1 and PCo2 of the Principal Coordinates Analysis.

Fig. 8. Results of seriation of the incidence matrix by the method of Brower and Kile (1988) with unconstrained setting (i. e. changing the order of both in cases and variables).

Fig. 9. Correlation matrix (correlogram) summarizing in color (sense of correlation) and intensity (degree 
of correlation) the relationship between the obtained scores (or order) from ordination methods PCA (PC.1-PC.10), PCO (Coord1-Coord10), Correspondence Analysis (Axis 1-Axis 10) and seriation (ordBK) on the whole set of the analyzed data.

Fig. 10. Correlation matrix (correlogram) summarizing in color (sense of correlation) and intensity (degree of correlation) the relationship between the obtained scores (or order) from ordination methods PCA (PC.1-PC.10), PCO (Coord1-Coord10), Correspondence Analysis (Axis 1-Axis 10) and seriation (ordBK) with absolute radiocarbon $\left({ }^{14} \mathrm{C}\right)$ data for the subset of cases (graves) with available absolute data.

Fig. 11. Scatter plot of PC8 scores from the PCA (on the $y$-axis) against the valuse of uncalibrated absolute data for a subset of graves with available absolute data.

Fig. 12. Column plot of loadings of variables on PC8 from the PCA, for comparison with the Fig. 11 (y-axis).

Fig. 13. Qualitative clusters of absolute data from Nitra Culture graves with median marking.

Fig. 14. Nitra culture in Moravia and Silesia. Overview of calibrated radiocarbon data. OxCal program v.4.3.2.

Fig. 15. Grave inventory of the Protonitra phase (NK1). After Peška/Šebela 1992, modified.

Fig. 16. Opava-Vávrovice-Krásná pole. Inventory of grave 15 of the Protonitra phase (NK1).

Fig. 17. Holešov-Zdražilovsko. Selection of the oldest graves in the cemetery - early phase of Nitra Culture (NK2). After Ondráček/Šebela 1985, modified.

Fig. 18. Holešov-Zdražilovsko. Inventory of grave 160 - early to older phase of Nitra Culture (NK2-3). After Ondráček/ Šebela 1985, modified.

Fig. 19. Holešov-Zdražilovsko. Inventory of grave 361 - early to older phase of Nitra Culture (NK2-3). After Ondráček/ Šebela 1985, modified.

Fig. 20. Holešov-Zdražilovsko. Inventory of grave 46 - older phase of Nitra Culture (NK3). After Ondráček/Šebela 1985, modified.
Fig. 21. Holešov-Zdražilovsko. Inventory of grave 84 - older phase of Nitra Culture (NK3). After Ondráček/Šebela 1985, modified.

Fig. 22. Holešov-Zdražilovsko. Inventory of grave 310 - older phase of Nitra Culture (NK3). After Ondráček/Šsebela 1985, modified.

Fig 23. Holešov-Zdražilovsko. Inventory of grave 10 - classical phase of Nitra Culture (NK3). After Ondráček/Šebela 1985, modified.

Fig. 24. Holešov-Zdražilovsko. Inventory of grave 76 - classical phase of Nitra Culture (NK4). After Ondráček/Šebela 1985, modified.

Fig. 25. Holešov-Zdražilovsko. Inventory of grave 91 - classical phase of Nitra Culture (NK4). After Ondráček/Šebela 1985, modified.

Fig. 26. Holešov-Zdražilovsko. Inventory of grave 78 - postclassical phase of Nitra Culture (NK5). After Ondráček/ Šebela 1985, modified.

Fig. 27. Holešov-Zdražilovsko. Inventory of grave 154 - postclassical phase of Nitra Culture (NK5). After Ondráček/ Šebela 1985, modified.

Fig. 28. Holešov-Zdražilovsko. Inventory of grave 391 postclassical phase of Nitra Culture (NK5). After Ondráček/Šebela 1985, modified.

Fig. 29. Přerov-Předmostí 7-Malé Předmostí Grave 10. Inventory of the grave of the Protonitra phase (NK1). After Peška/Hadrava/Šín 2019, modified.

Fig. 30. Osek nad Bečvou 2-Nademlýnice. Floor plan of a grave pit with the placement of the skeleton of an adult woman and two children with all equipment. After Peška/Tajer 2015b, modified.

Tab. 1. Nitra Culture in Moravia and Silesia. Selection of calibrated absolute data for independent verification. OxCal program v.4.3.2. 